Portland State University

PDXScholar

5-24-1971

\title{
The Effect of Antibiotics on Thermophilic Blue-Green Algae
}

Erleen Blanche Christenson

Portland State University

Follow this and additional works at: https://pdxscholar.library.pdx.edu/open_access_etds

Part of the Bacteriology Commons, Plant Biology Commons, and the Plant Pathology Commons Let us know how access to this document benefits you.

\section{Recommended Citation}

Christenson, Erleen Blanche, "The Effect of Antibiotics on Thermophilic Blue-Green Algae" (1971). Dissertations and Theses. Paper 1451.

https://doi.org/10.15760/etd.1450

This Thesis is brought to you for free and open access. It has been accepted for inclusion in Dissertations and Theses by an authorized administrator of PDXScholar. Please contact us if we can make this document more accessible: pdxscholar@pdx.edu. 


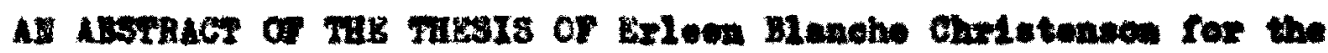
Hater of selmoe in Holos promented un $24,297$.

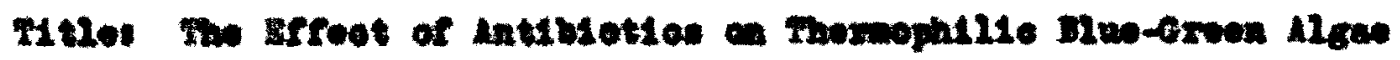

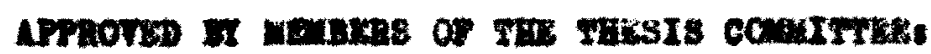

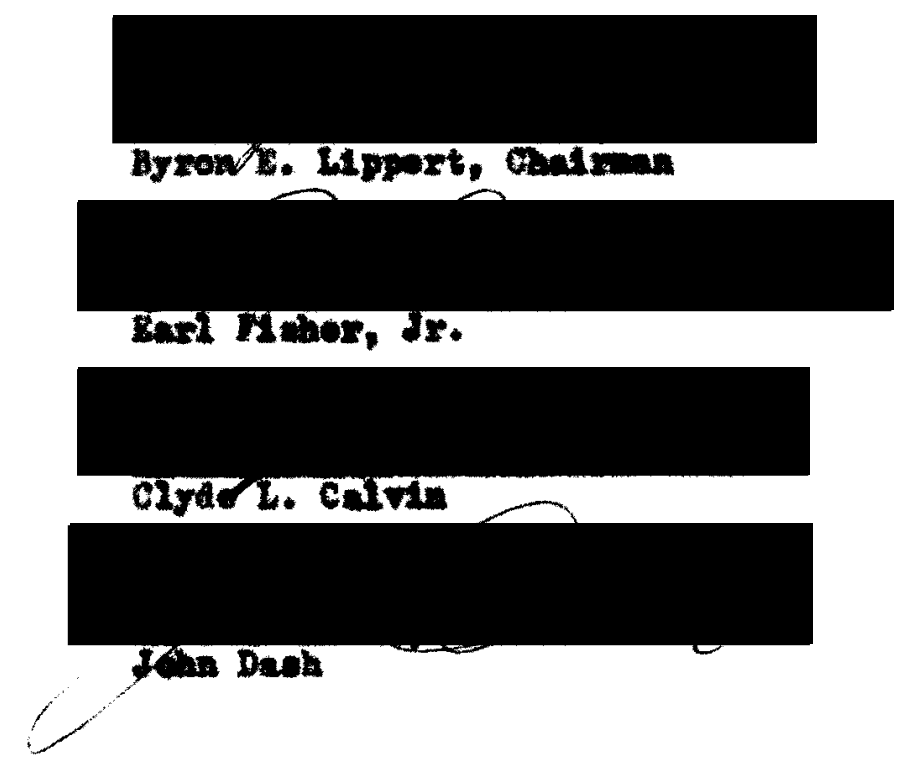

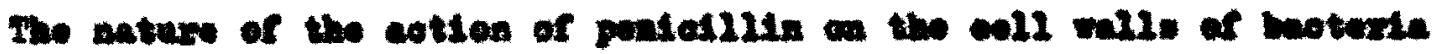

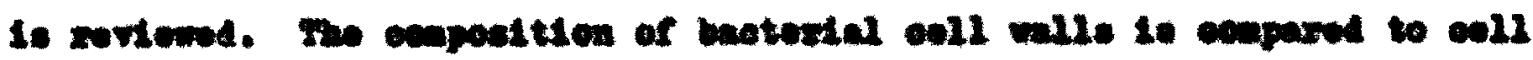

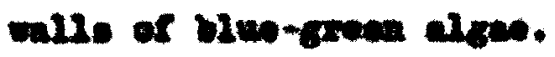

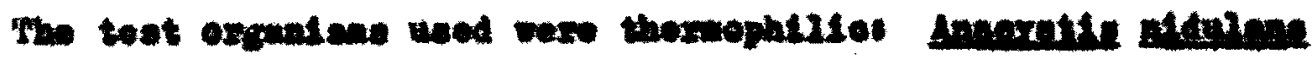

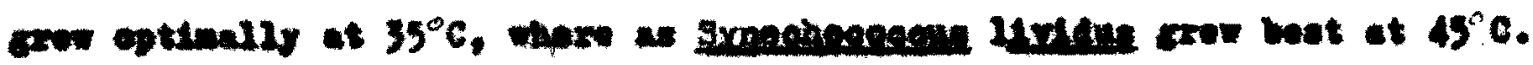

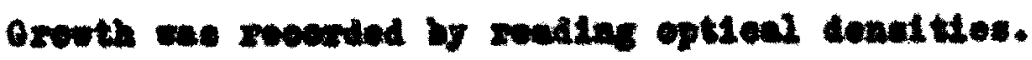

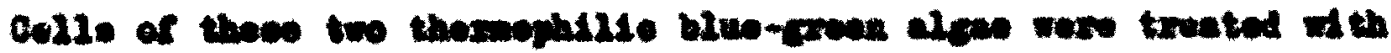

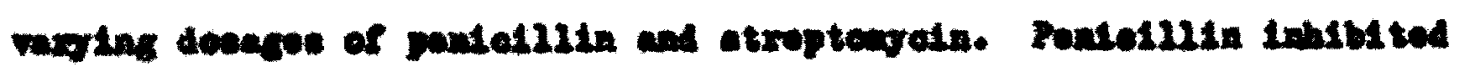




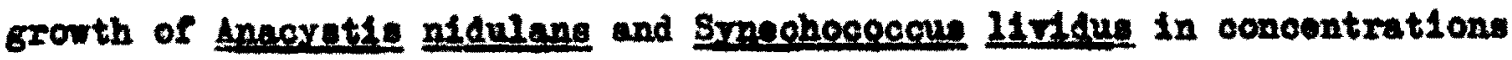
of $3.0 \mu \mathrm{g} / \mathrm{ml}$ and $0.03 \mu \mathrm{g} / \mathrm{ml}$ respectively. Eowever, when $0.3 \mu \mathrm{g} / \mathrm{ml}$ of pentolllin was added to Angexatis nidulang, an Intitial los phase of growth was observed. Possible reasons for this lag are suggested and renults of pertinent experiente are dsoused. Ho similax lag was noted in Syneohoopogan 1iridus.

Streptomyoln inhibited growth of both speoles when present in $0.03 \mu \varepsilon / m$. 


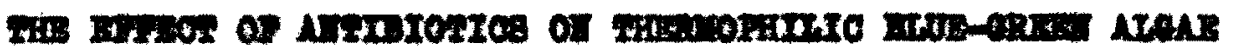

b

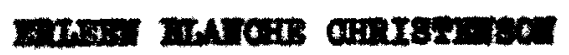

A thode culntited in partin suringent of the reguedrenente for the degee of

Mardat or sother

in.

Erosos

Poxtland state Batrexadts

197. 
TO THE OFTCE OP GRADUATE STUDLAS

The nembers of the Comittee approve the thesis of Exleen Blanohe Christemeon presented May 24, 1971.

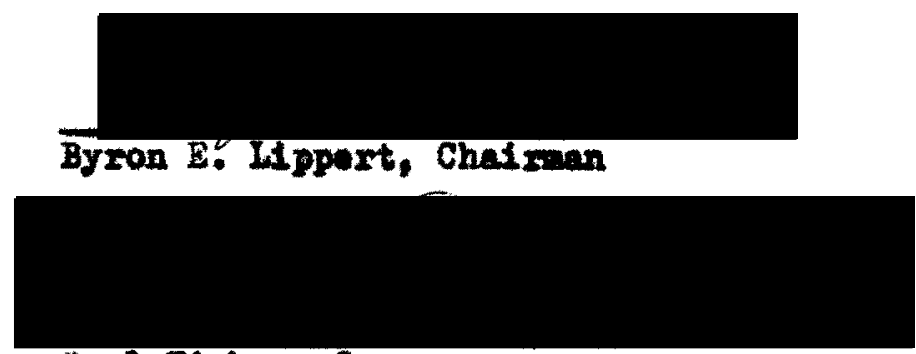

Barl Plahex, Jx.

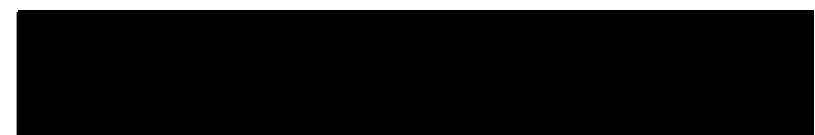

Clyde 1. Calvin

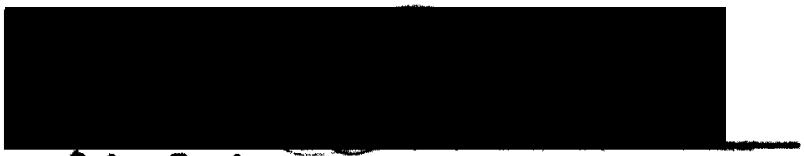

John Desh

APPROVD:

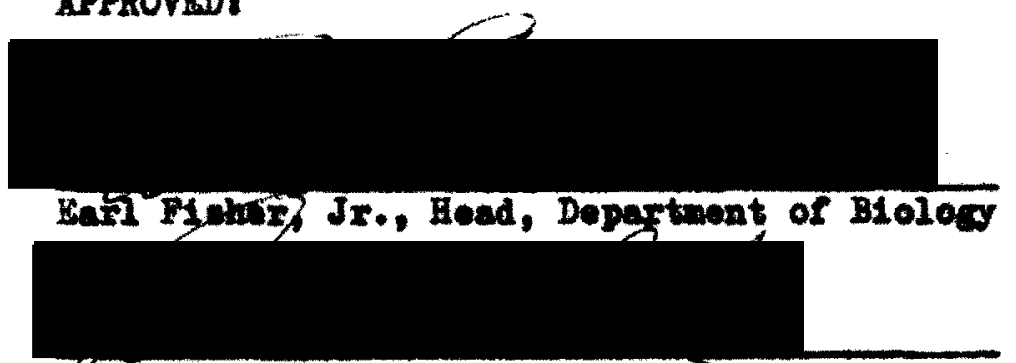

Dafid T. Claxk, Dean of Graduate Studios

un 24, 1971 


\section{ACKWOALEDGEMENTS}

The writer would like to thank Dr. B. E. Lippert for advioe and assiotance in the experimontation, for ohooking this manusoript with his ever ready red pen, and for introducing her to the marvelous world of algae. Thanks also to Dr. Earl Fisher, Jr., who as my f1rat adrsor, gave encouragenont when it was needed. And a opeodel thank you to wy husband, Mes, who programed the data for the graphs, and also served as payohologlat, morale builder, and helpmate these pest two years. 
TABLE OF CONTENTS

Pace

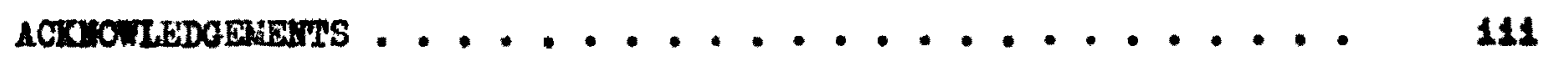

LIST OF TABLES ..................... vi

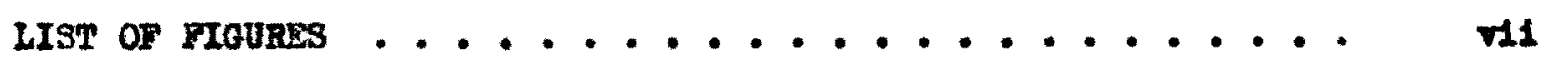

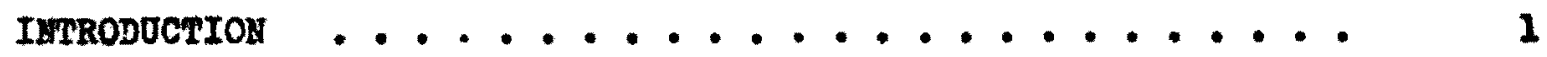

Mucopeptide In the Cell wall ............. 1

Erldeno For Prosence of Mucopeptide In Blue-Green Algee .......... 3

Mechantis of Action of Pentolilin ........... 7

The Aotion of stroptomyoin ............. 10

Proviou Wort or Antibiotio Effeot

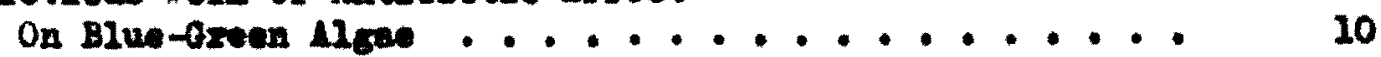

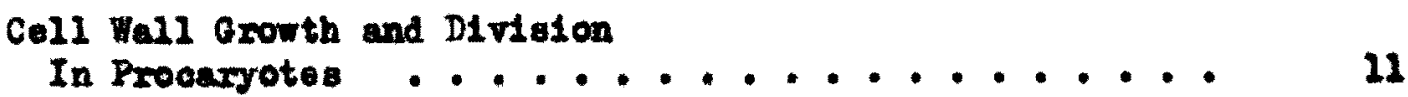

Desoription of the Problen .............. 12

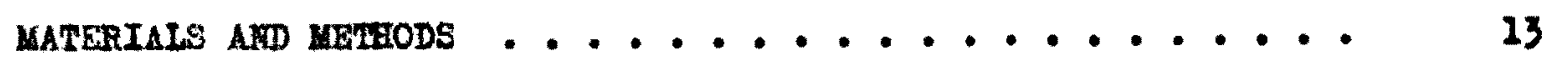

The organtms ............................ 17

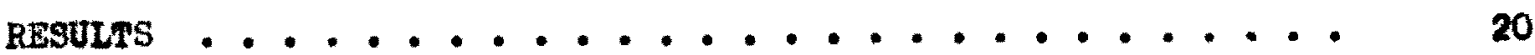

Optisal Temperatures For Thorwophtile Organt ans ..... 20

Cell Counts .................... 23

Effeat of pH on browth ............... 23

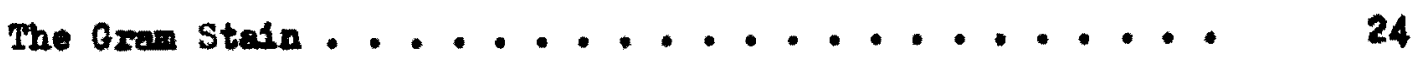

Effoot of Pondatzlin on $\ldots$............... 27 
Probable Explanations Por Survival

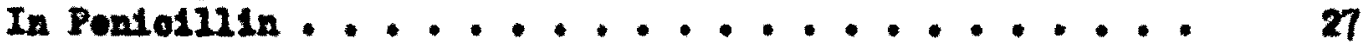

Erfoot of Pentolilin on

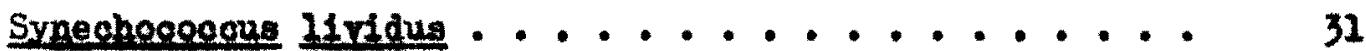

Bffeot of streptonycin on

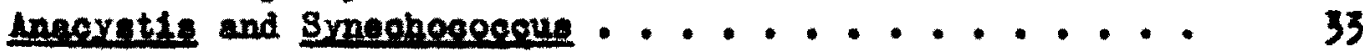

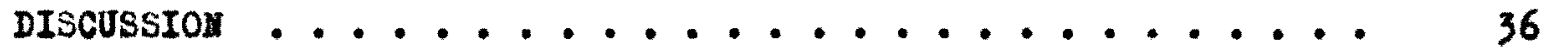

Sugrestions For Further Researoh ........... 39

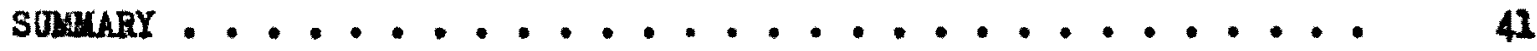

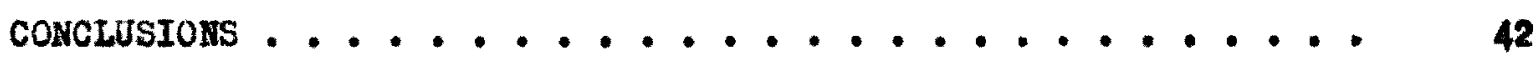

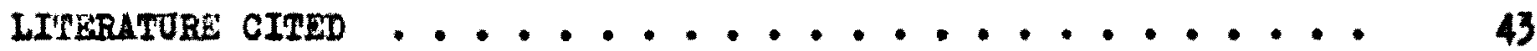


LIST OF TABLES

Page

TABLE

1 Principel compononts or coll wall. .........

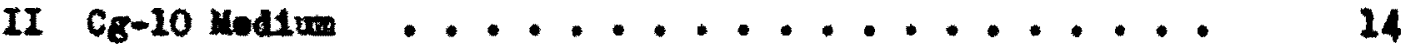

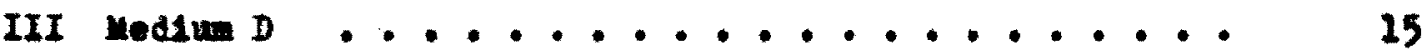

IV Changes In fi 1000mpanyiag 0rorth or Smeohoogone Ifridus .......... 25

$\checkmark$ Changes In pll Nooctopanylag Growth of Anoretil nlduieng ............... 26 
LIST of rovas

Page

FIOUn:

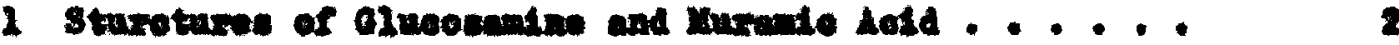

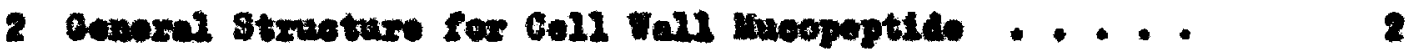

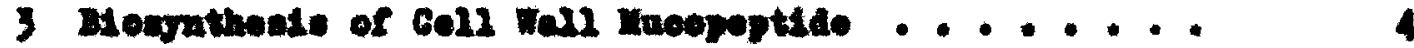

4 Stallar strantures of DAP and Lrate .........

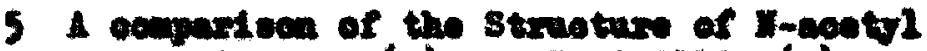

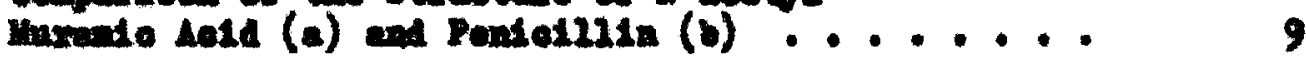

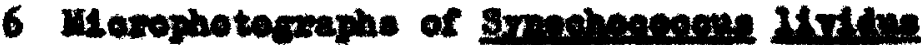
mantie niteine $\ldots \ldots \ldots \ldots$

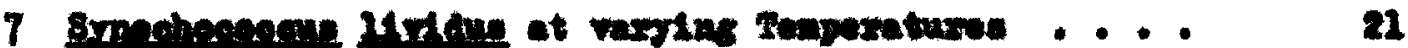

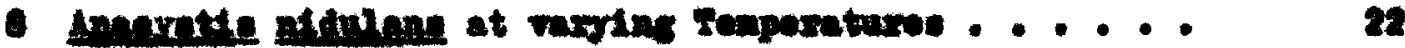

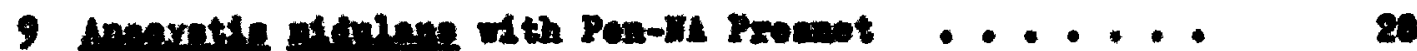

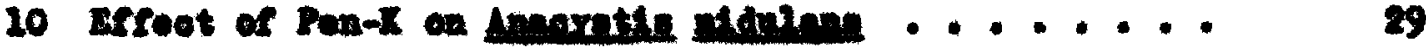

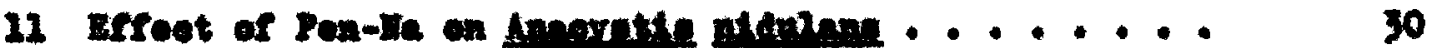

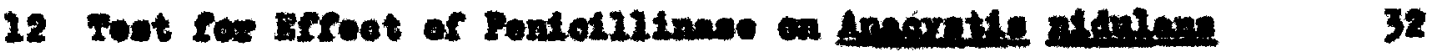

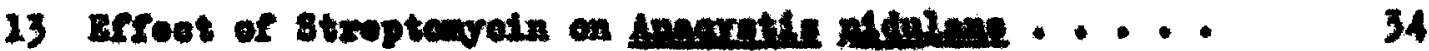

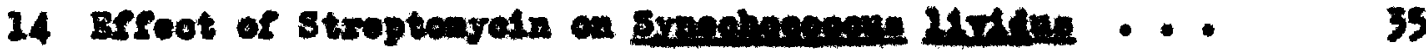




\section{IETRODUCTIOA}

Blue-green algae dlffor Irom othor algae, in that thoy lack woll

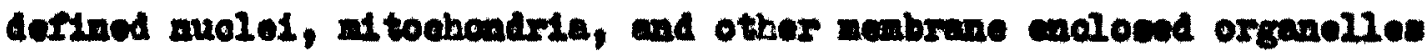
normally found in the eolle of eucaryot1e algat. In these respecte, bluo-green algac are nore etmilar to bastorie and it is from this posnt

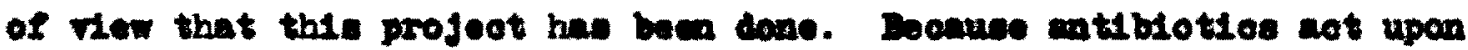

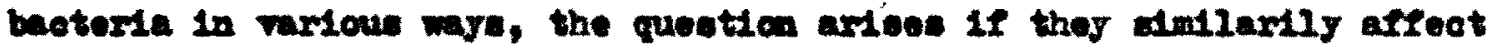
blue-groen algee, alosely related progaryotes. In bateria, pentolllis intermapte the aynthente of the oell well and primaxy atteation here has boen almod at determinting whether or not this is aleo the case in these

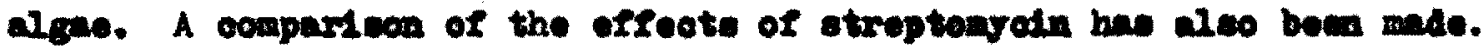

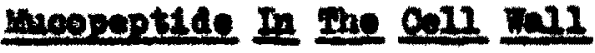

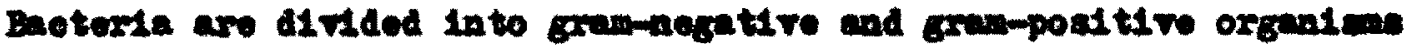

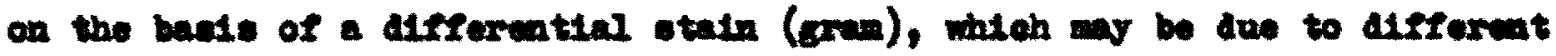
pormability properties of the oell wil. All bacteria inveotlogted

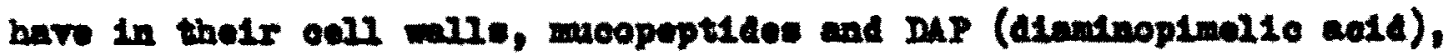
whloh wre apparmatly ouly found in procaryotio orgenilme. Oram-posttive organt on may have croctor then $50 \%$ of the ooll wall compoead of moopept1de while grom-aegative organien have 5-10\%, This moopoptide 10

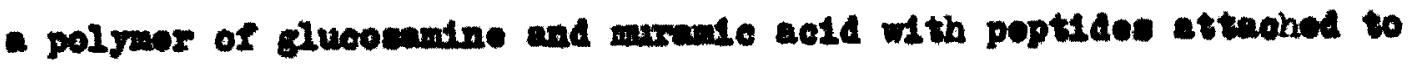

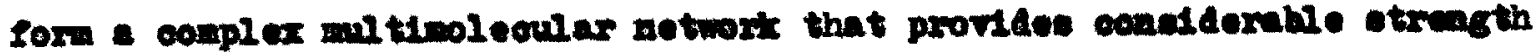
to the wall (Yandelotan and Moquillen, 1968, Hordkorf and Boltmen, 2970). 
The repeatins unt to of the meopoptide, gluoesanino and muranto ootd, aro shom in Here 1.

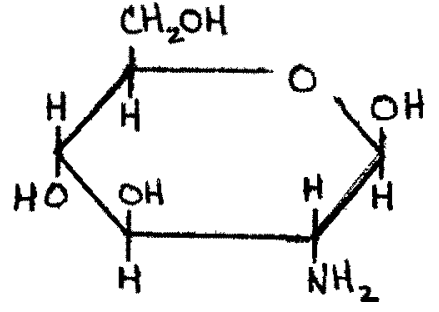

Qlueosanine

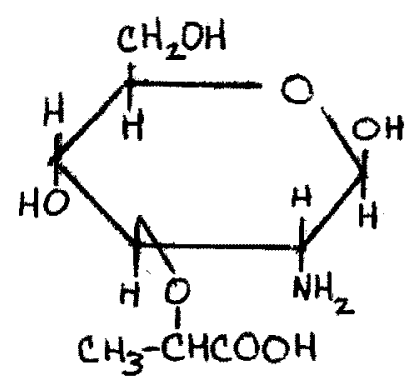

Mranto actd

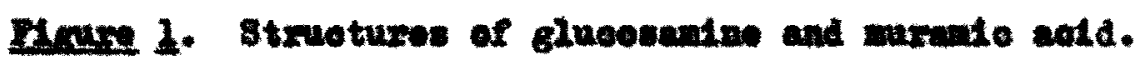

The antino group in thoes cowpound is nowally not fros bat is combinod

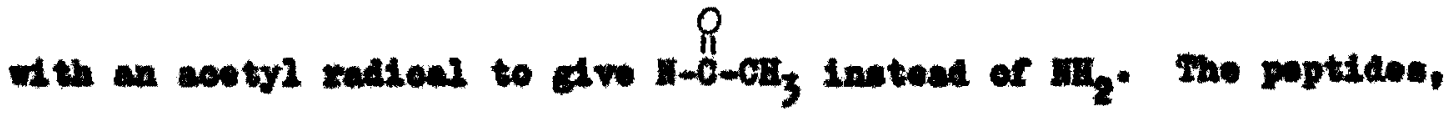

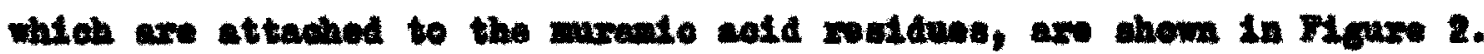

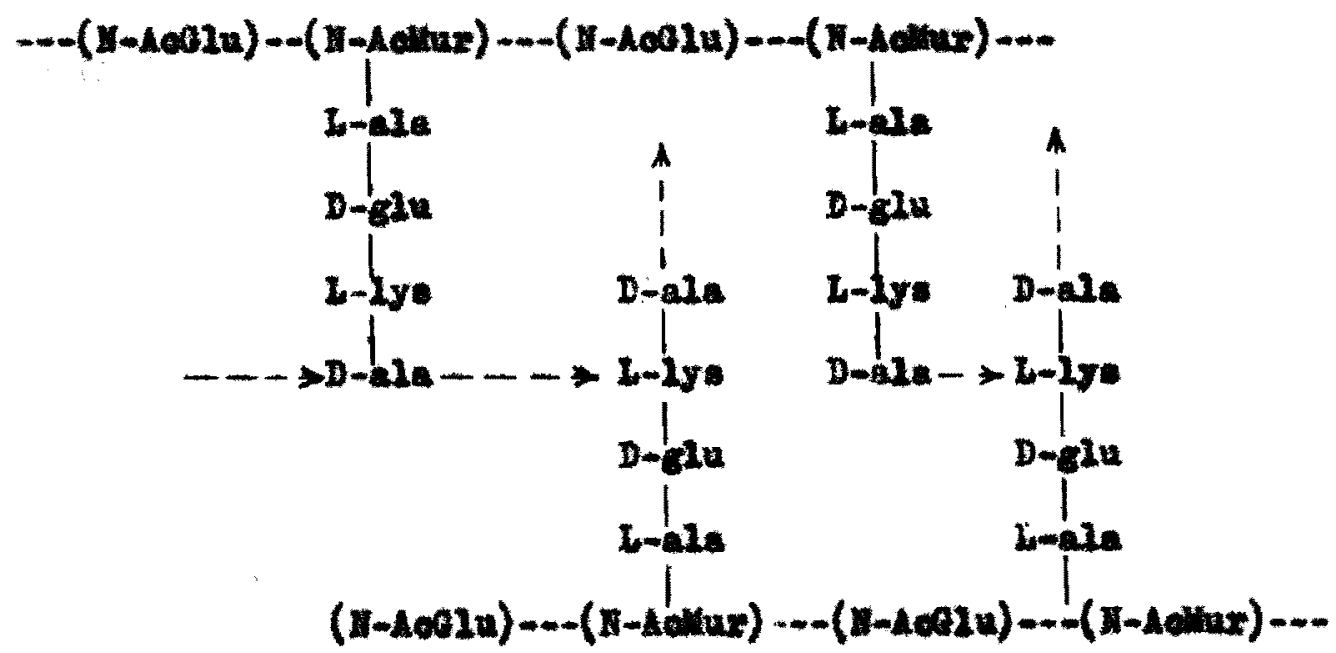

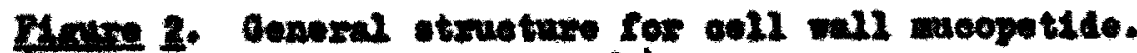
(Fro rivan and Codeach, 1967).

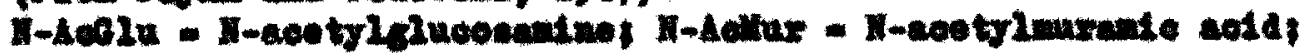
giv - dutende waldy Iy - 2 rodne.

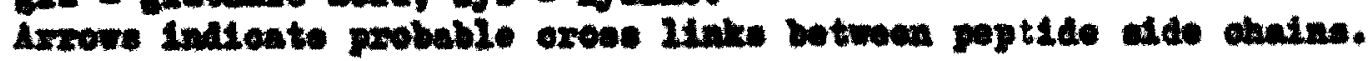


The peptides are composed of a lint ted range of ambo solde. Alanine and glutamio acid are al way found, togethor w th o1 ther diaminopimollo

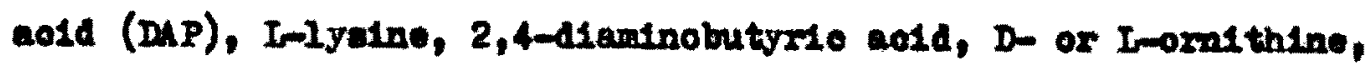
61jolne, or D-appartio actd (Rogere, 1963, Vandelotan and Mequillen, 1968). Wost of the Glutamio actd and about hale of the alanine is provent as the wowealled 'unatural' D-1 somer and this, together 1 th the occurrenoe of maramio aold and DAP may be partially respongible for the propertiee posesesed by the moopoptide. The bloayntheale of cell wall mucopept1de 1s ahom in Flgure 3.

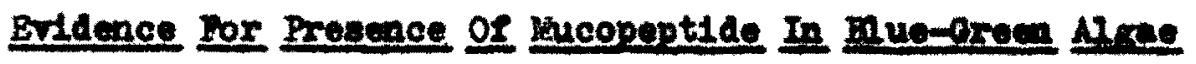

Salton (1960) reported the presemes of moopoptides in bluo-grocen algae. It 18 koon that in beoteris the aymonte of this compound is blocked by peatetilin (Fart and stromingex, 1937). Beoawee of the

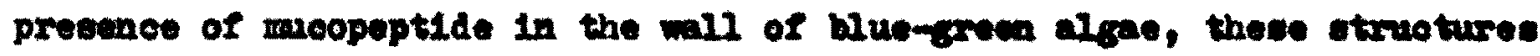
my also be seneftive to the blosynthetio blook brought about by

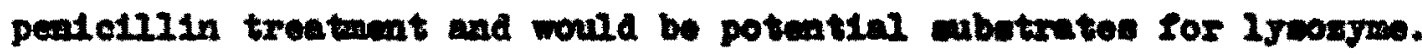

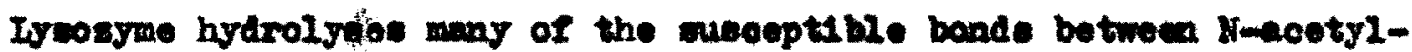
murande ac1d and I-acotylgluoosemine, and the cell wall 10 digeoted. It has been demonotrated that both direot treatment of 1solated mils wh lyeosyme and growth in the presence of pentelizlin could be ued effectively

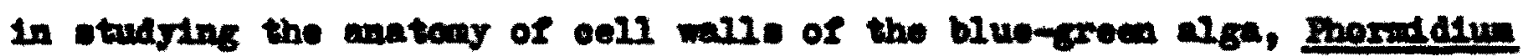
molnation (Frank, Iefort, and Nartin, 1962). Quantitat1 ve ahemical andrale of 1eolated oell walle of thise organlew showed that the meopoljmer componcent resembles the compostion of the coll walle of gram-

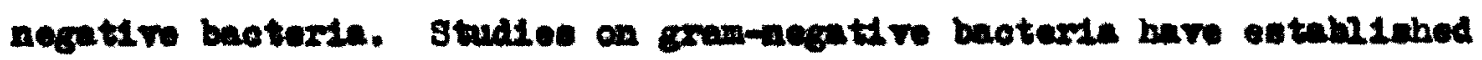




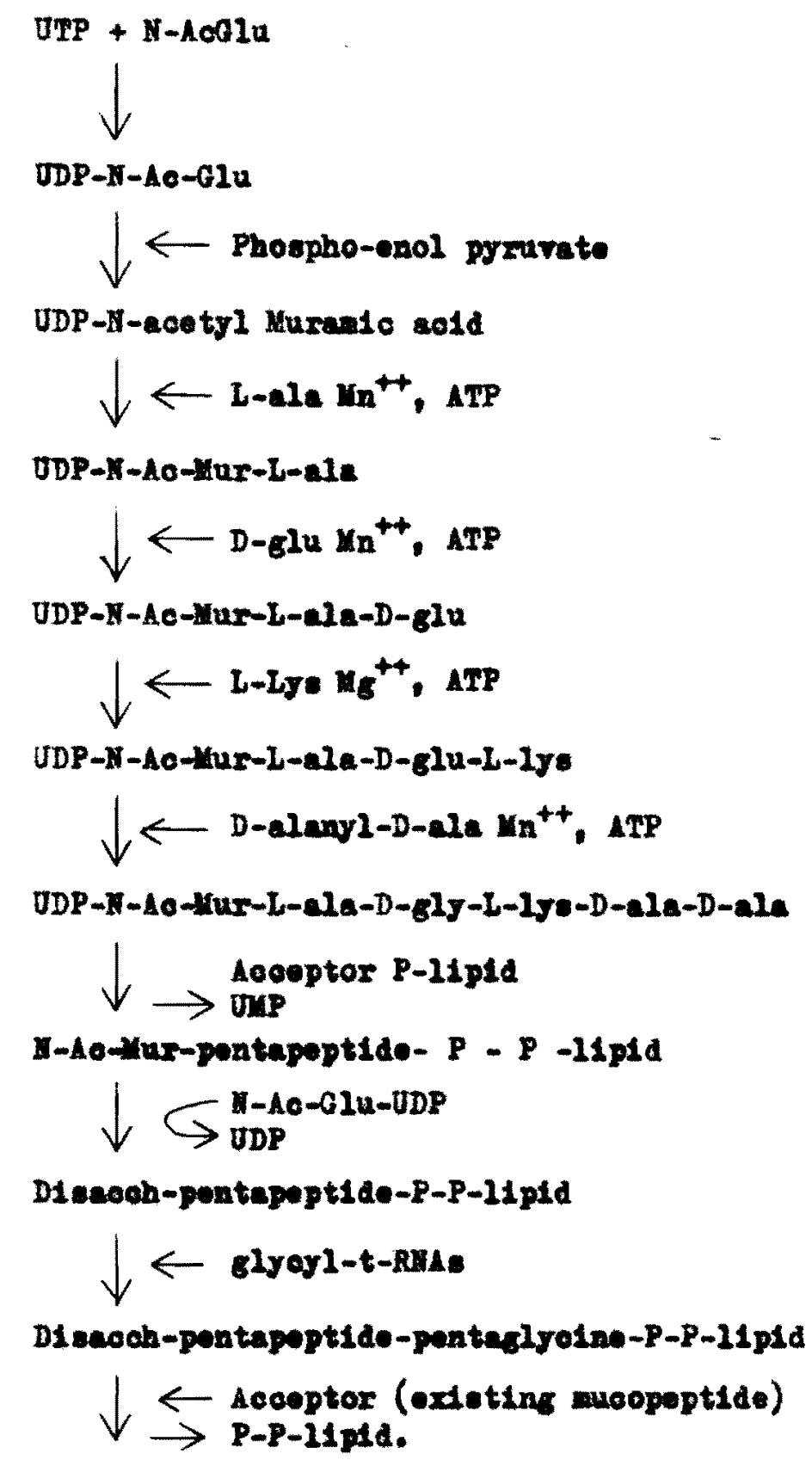

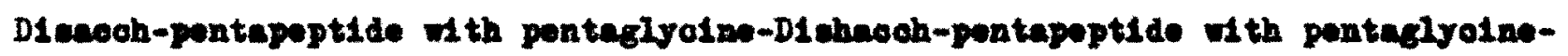
$\underset{\text { Pontollin blooke }}{V}$

Crove-1Lik exeopoptide + D-elentue

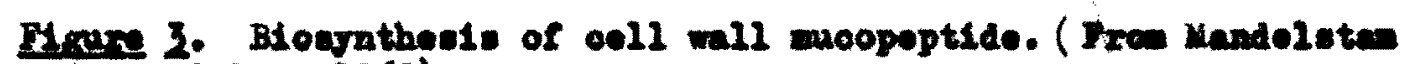
and Mopuillen, 1968). 
that the muoopolymer layer is electran dense and lies noxt to the oytoplawio zonbrane (Salton, 1964). Purther work on becterla ind1catos

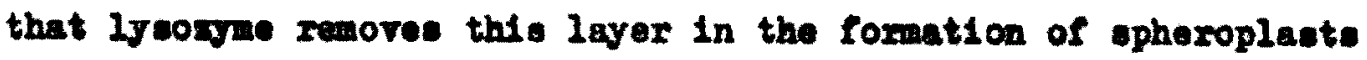
(Murray et al., 1965). The Inner layer of the cell wall of Aneorstie pidulans was removed by the lysosyme in the formation of spheroplasts, Indioating a posalble alailarity betwen this layer and the eleotrondense mucopolymer layer in gron-negative bacterisl oell walls (Lindsey et al., 1971). Similar ultratructural Investigation of ghoretdiun by frank (1962) ohowed that the muoopolyner supporting meabrase, whitah 18 apparently responelble for the migldity of the cell wall (Feidel and Prinoe1gh, 1957, we1del et al., 2960), could alwo be digented by 1yconyme.

Lyeosyme is a one-chaln protein with a mequance of 129 anino aold maldues known (Mahler and Corden, 1966). Lysonyme exerts 1ts most

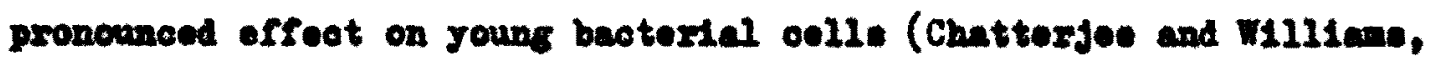

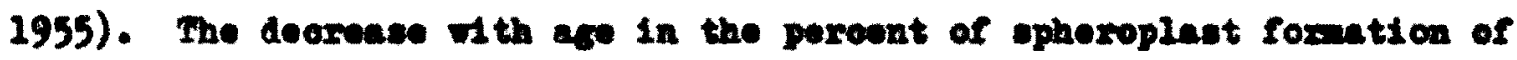

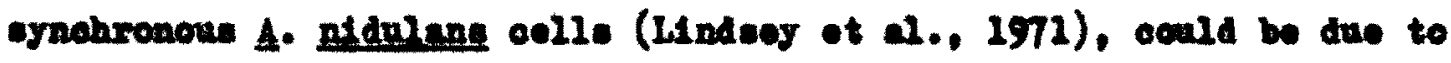
netabolle differonoes in the oelle or to varlations in the anount of

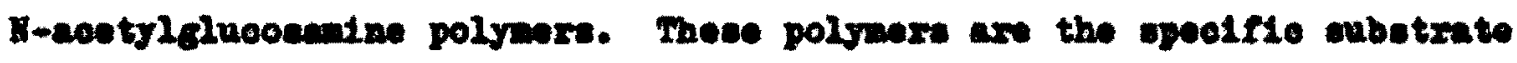

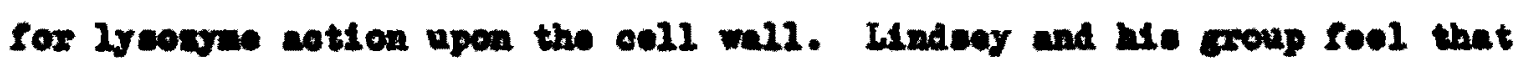
the renpones to lynoayne cotion my be altered by the frequenay and

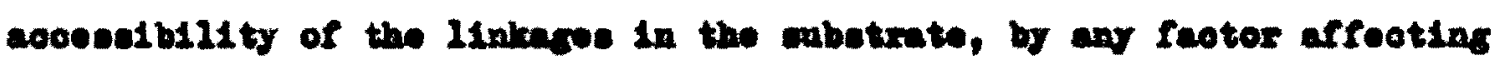
the etability of the oell gurfaos etructurs, or by axy mbetanos bloaking

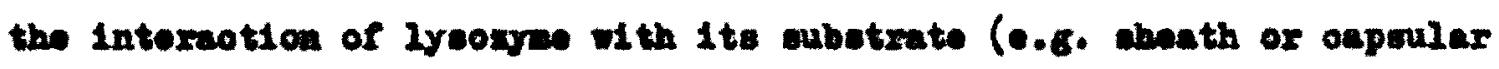

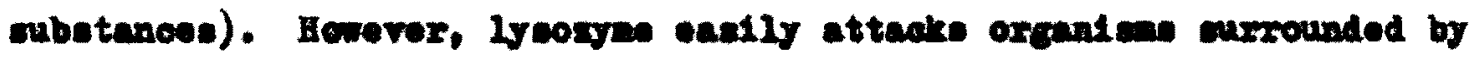

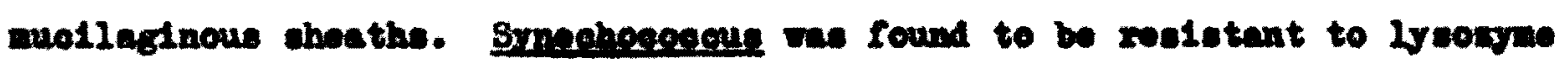


(Creop1, 1962) and 1t is whout an ordent golatinowe shoath. Smechoposone may have more oomplloated coll wall or Crespl may be correot by Inferring that distinotly aheathed algae probably oontain rolatively groter anounte of muranie aold and moopolypoptide ingortant constituente of the cell wall.

Holm-Eansen (1965) roported DAP was prosent in 소 nldulang and other blue-green algae. DAP was found in the bound form as component of a mueopeptide of the oell wall. DAP, unlque to procaryotes, has a - truoture almilar to lyoine (See Figare 4).<smiles>[1H]C([18OH])(CCCCC(=O)O)C(=O)O</smiles>

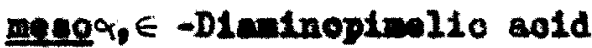

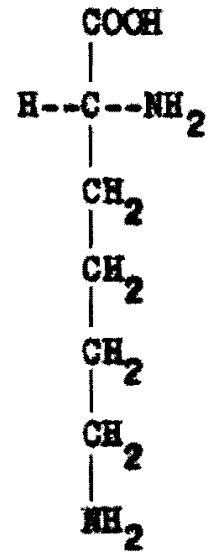

Lyaino

Alare 4. Sindlar etruotures of DAP and 1Yateo.

Lyatine 10 sonotione replaced by DAP in the moopeptide.

Drows and leyer (1964) found the woopolyner conponente

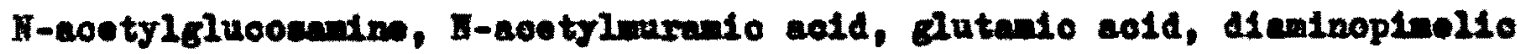
ac1d, and alanine in the blus-groen algee, Chloroxloes and Anegretis. Isolated coll walle were lyeed by 2 yeonye, but wole colls wese transformod into sphoroplasts any by adding ethylome dianino totre-eotie wold. Thoce feote again suggest that blue-creen algal walls ars oquippod 


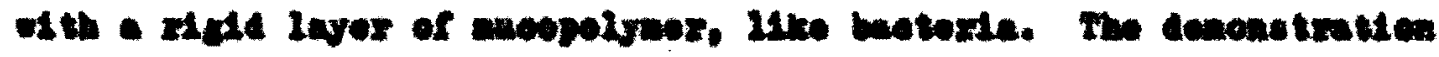

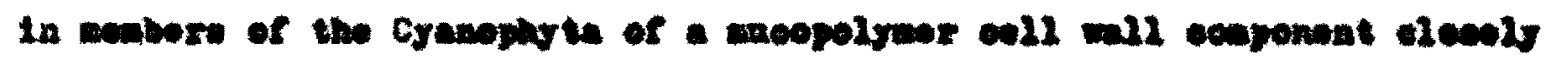

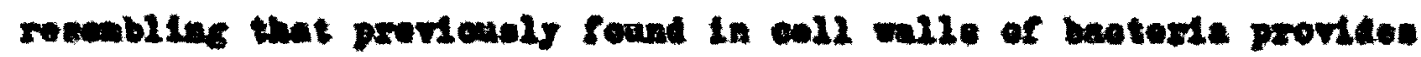

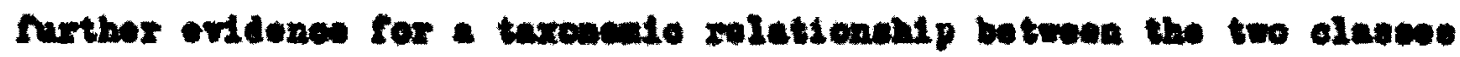
of arganteas (see rable I).

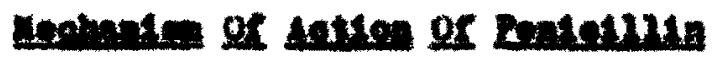

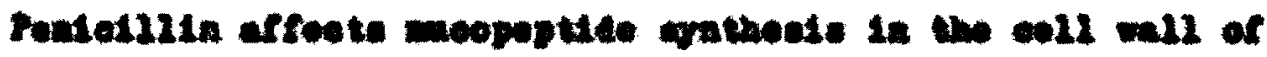

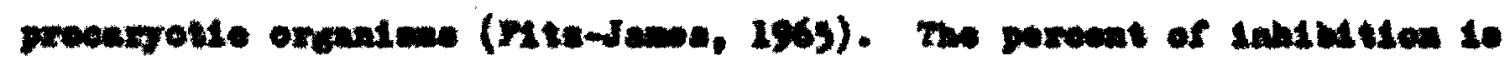

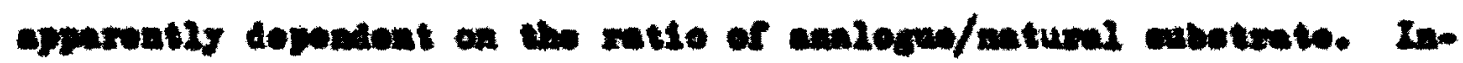

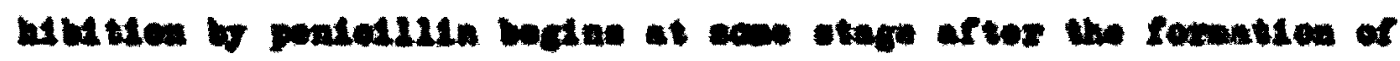

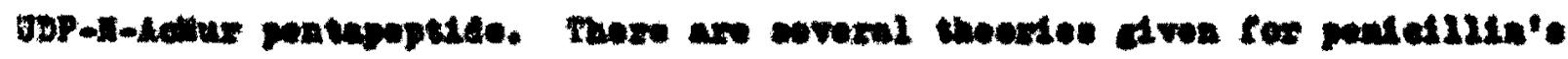

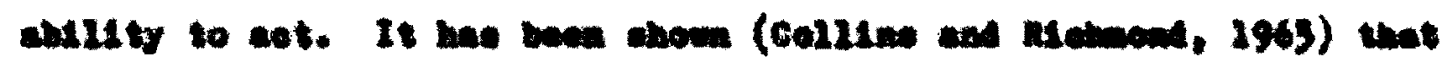

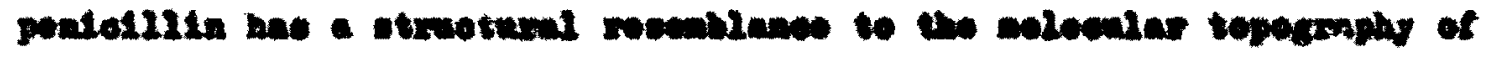

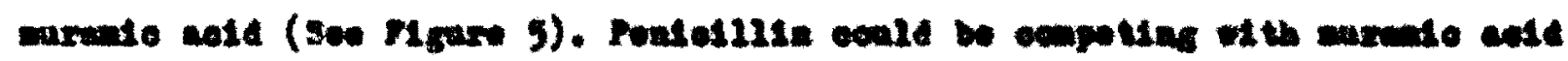

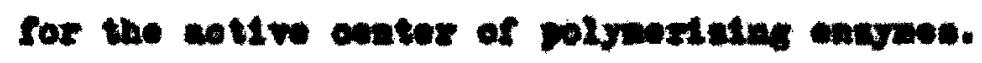

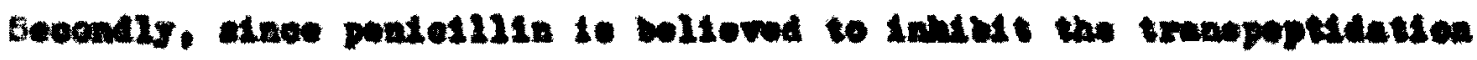

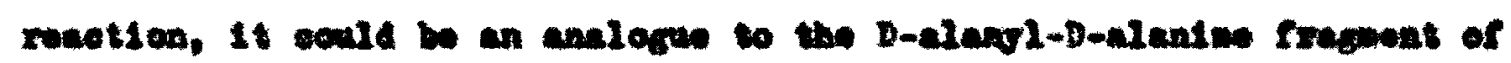

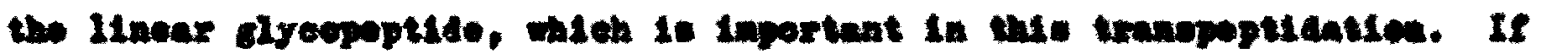

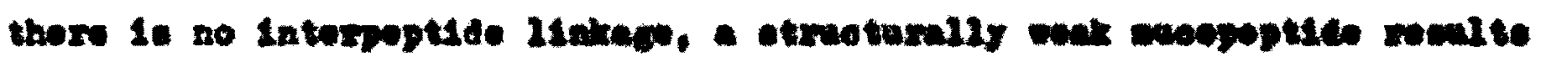

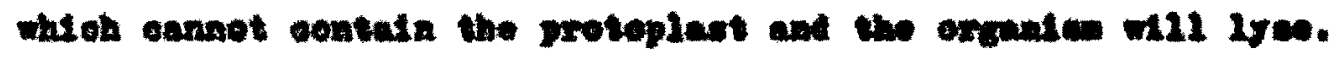

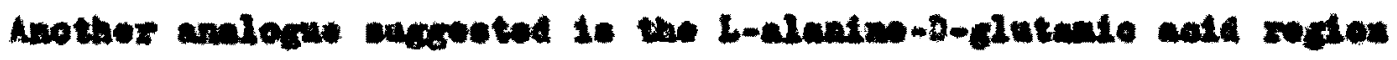

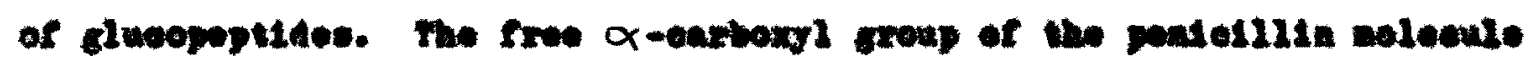

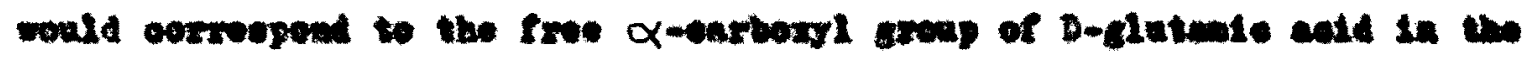

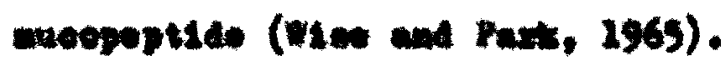


WuLE 1

PRIICIPAL COAPOHEATS OF CELL waWh

\begin{tabular}{|c|c|c|c|}
\hline COMPOXENT & $\begin{array}{l}\text { GRAM + } \\
\text { BACTRIA }\end{array}$ & $\begin{array}{l}\text { GruY - } \\
\text { BACTERT }\end{array}$ & $\begin{array}{c}\text { BLUS-QRESA } \\
\text { ALOAB }\end{array}$ \\
\hline Mneopept1de & + & + & + \\
\hline Poly ancohartde & + & + & + \\
\hline Toloholo eeid & + & + & \\
\hline Teioluronic ao1d & + & & \\
\hline Protein & + & + & + \\
\hline Lipld & & + & + \\
\hline L1 popoly sesohartde & & + & $?$ \\
\hline Lipoprotein & & + & $?$ \\
\hline
\end{tabular}

Information on beotorial cell welle Iron Mandeletem and Yoquilien (1960). Information on algal ooll walle from Drowe and Hoyer (1964) and Punnott and Derronbeaker (1966). 


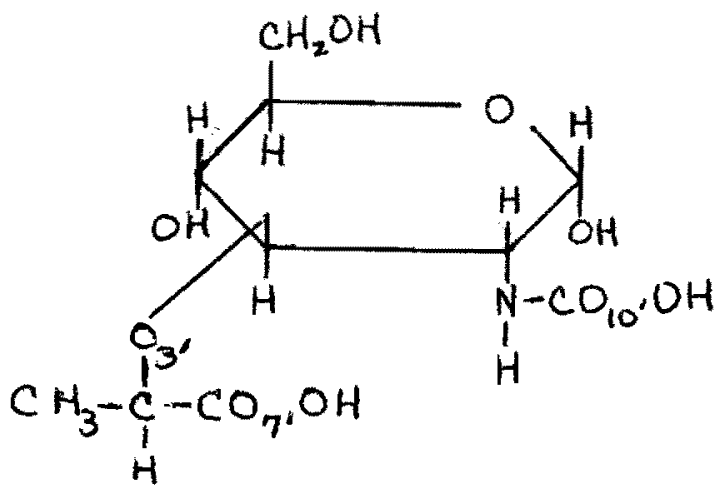

(a)<smiles>[R]N[C@]1([N+](=O)[O-])C(=O)N2[C@H]1SC(C)(C)[C@H]2C(=O)O</smiles>

(b)

P4axe 5. A comparison of the struoture of N-acetyl muranio aold

(a) and pantollila (b)

N-Aoe tyl maramio dold:

Ozi ther oxgen of leotyl aide obuin

9: carbonyl greup of carboxyl attached to $c$

qof oarbonyl oxjoen attached to $c_{10}$ in the li-acotyl rosidue. Pentoulin:

${ }_{1}$, txiply-subetituted altrogen of $\beta$-leotem ming

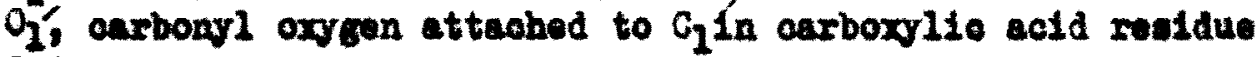

$0_{g}$, ourbonyl oxysen atteahed to $\mathrm{C}_{g}$ in the alde chaln

Oar arbonyl oxg gen attaohed to $\mathrm{C}_{8}$ of $\beta$-laoten bond.
(Taken from Rtaheond, 1966). 


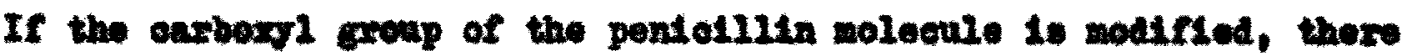
Is deoreased activity. Oxddation of the culcus in the thasolidine ring

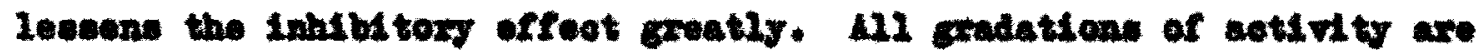

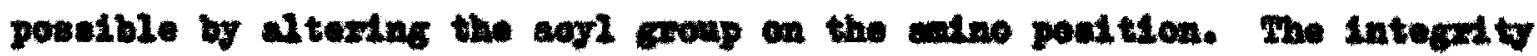

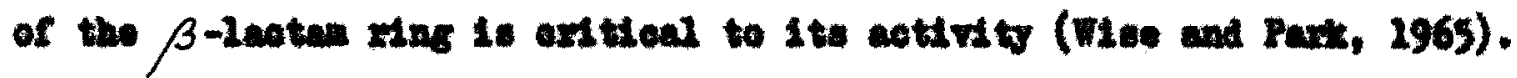

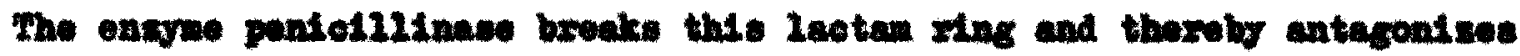
the antiblotte' ofreot.

\section{The Aatton of Strevtemrath}

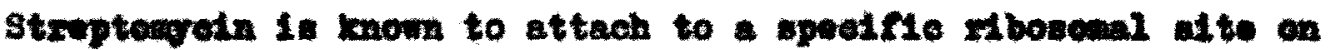
the 30-8 subunt of the atbosene (00x, 2964; Hahler and Coxter, 1966).

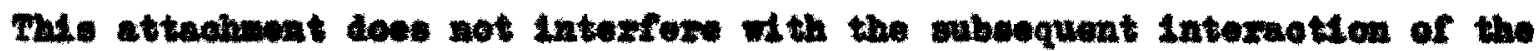

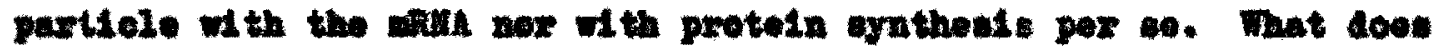
bappon as a result of the interastion, however, is that the altexed

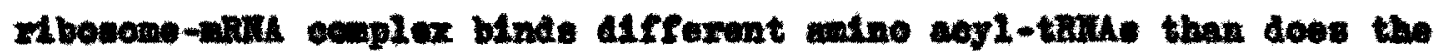

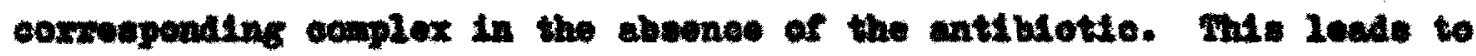
a wrong transletten of the cdvanolus negeengen tape. Clearly, woh

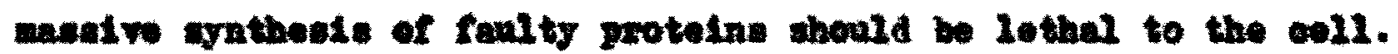

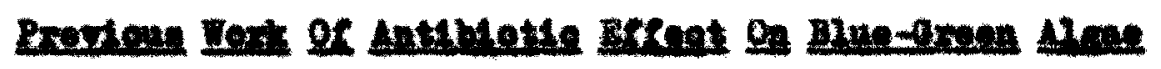

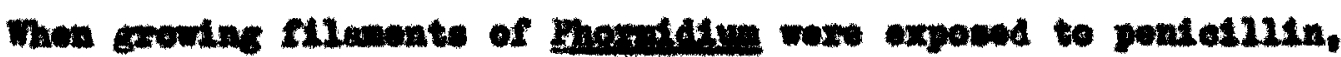

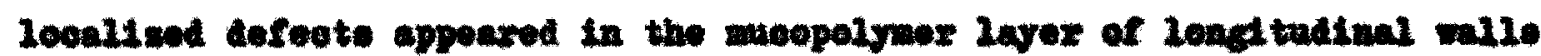
and In the ooxresponding larers of ocmplete and inocoplete oxeos mall

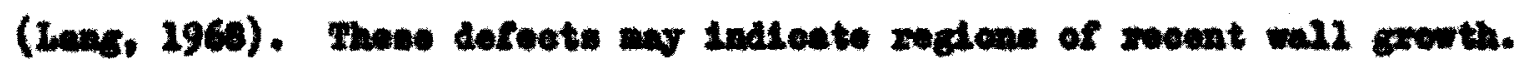

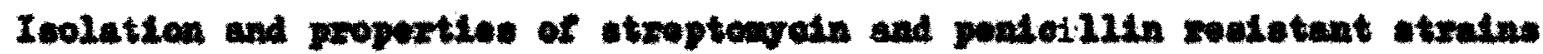




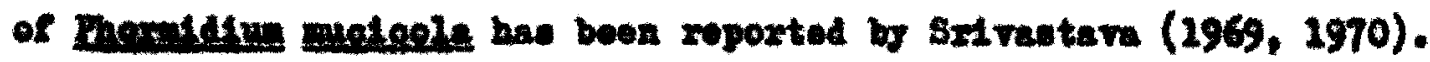

Eo found that paxent otraling could not survive boyend 0.2 and $0.2 \mu \mathrm{d} / \mathrm{m}$ of atroptorroin and pondedilin respootively. Oupte and Imax (1970)

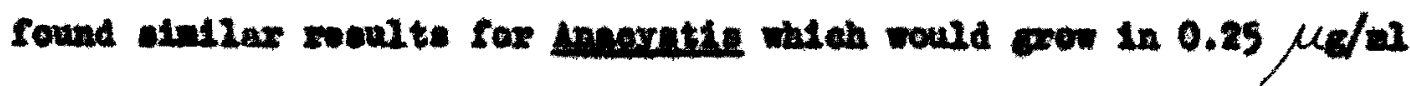

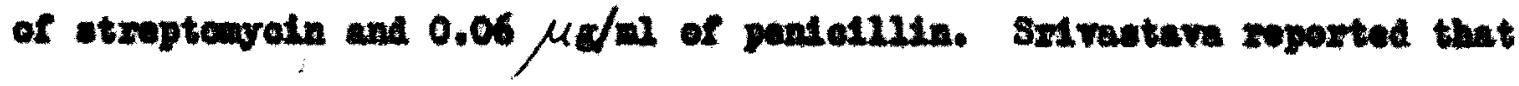

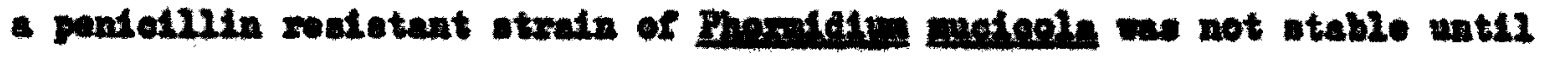

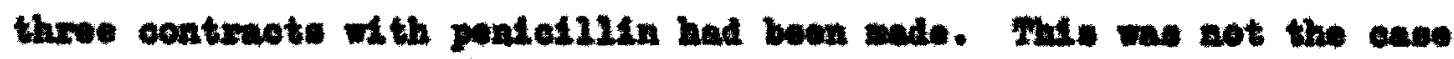

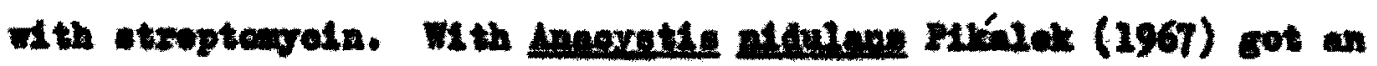

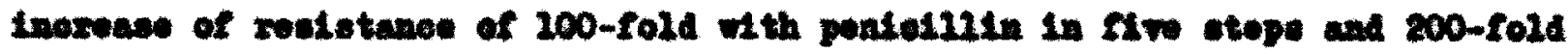

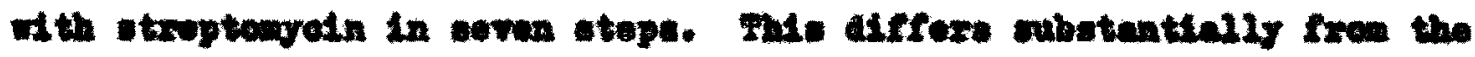

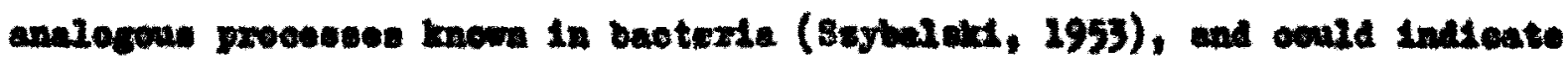

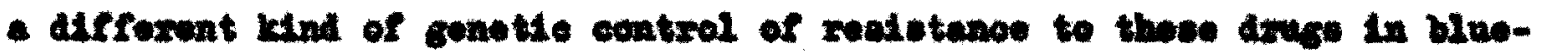
arean alges.

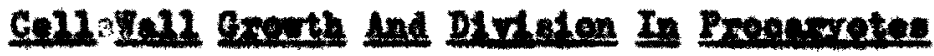

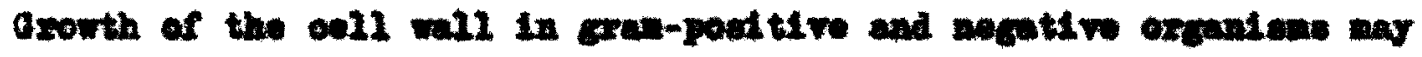

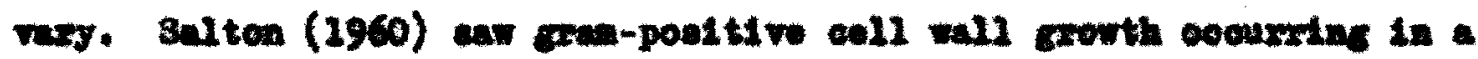

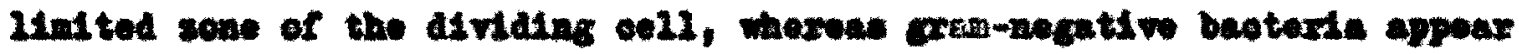

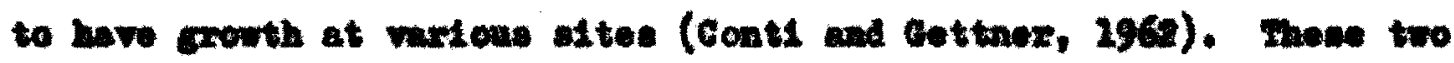

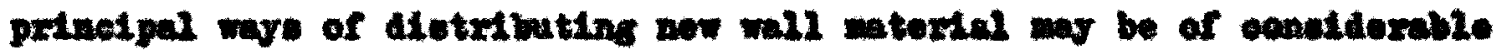

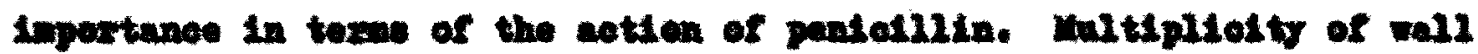

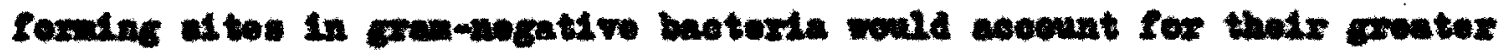

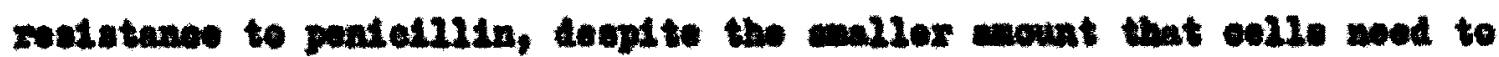
yrathosese.

Handelster and Mequallen (1960), hewrver, state that the type of

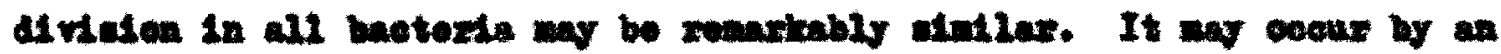


Inward growth of a soptum before cell divialon, as is the oase In blue-greon elgae (Destkachary, 1959).

\section{Deartiption of The Problem}

The purpose of the experinonts done was to study the erfects of

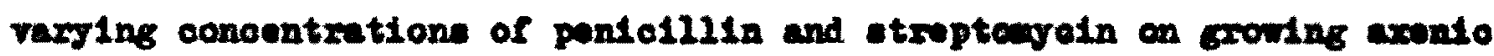

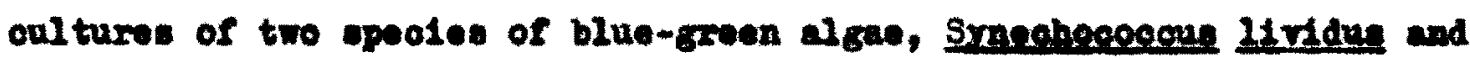
Angeratis nidulen. Growth ourres wese obtalned on the organiano growing In antiblot1e-contading modia and eleotron alorographs wore taken in an effort to 1lluatrate any visible obanges in the oell walla.

The blue-green algae used in this otudy were thermophilios

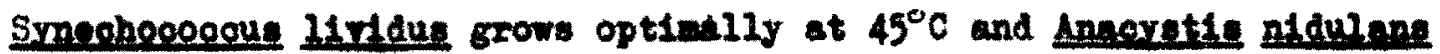
gxows best at $35^{\circ} \mathrm{C}$. Thls type of organlaten be more important in the ruture the tempereture of our waters rises wh inorealins pollution. In nature, Syaoohooocous outgrows other blue-greon algmo to are denee suspention block (Centonhols, 1969). Many blue-green algae have bigher temperature optima than evcaryotic organtene of the wase waters (Batterton and $\operatorname{Van} B a a l o n, 1968$ ), wo as the terperature rises these blue-greens beocme more of a problom. It seens quite probable that habitete of thermophiles wil 1aoreses in the ruture. 


\section{MATERIALS AND YEYEODS}

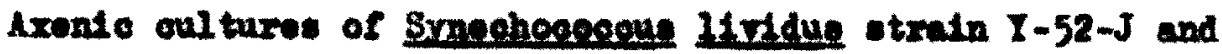

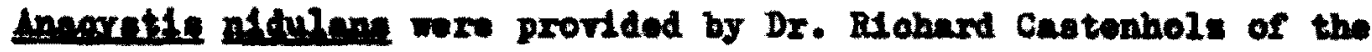

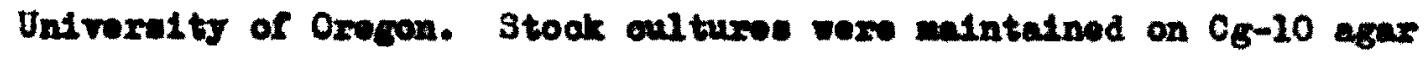
elente (Van Baclon, 1967) (Seo Table II). For experimental vork Involving arowth ourves, the elgee wore grom in defined $D$ modive (Castonholy, 2969) (See Table III). (Mod1s thet to known to bo apeotflo for blwo-groon algal oul tures, Krats and Kyers (Krets and Mrers, 1955) and Cranophyooan (Starr, 1964), d1d not mpport growth of these

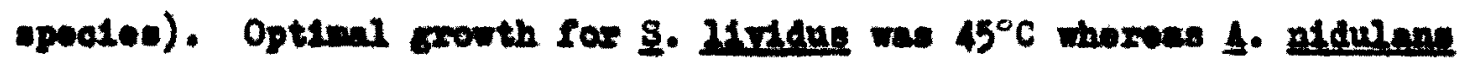
grov bot at $35^{\circ} \mathrm{C}$, therofore, experimontel work wa oarried out at these teaperatures. The $45^{\circ} \mathrm{C}$ tempexature was aoktered by ues of a constant-tenporabure water bath with a 116ht 1ntemelty of 400-510 ft-0. using oool-white Ruovereont tubes. The $35^{\circ} \mathrm{C}$ temporature was attalned In a Peroival onvirowental crowth ohamber model E-57. Wight intenolty raxied from 400-550 ft-0. At the ourface of the 116uid. Stook oultarea of S. Lrfidue were maintainad at $45^{\circ} \mathrm{C}$ and the stooke of $A$. Alidulane were kept at roow tomporature (0a. $25^{\circ} \mathrm{C}$ ).

A $0.2 \mathrm{ml}$ Inooulu from oul ture containlng $8.0 \times 10^{6} \mathrm{0ell} / \mathrm{ml}$

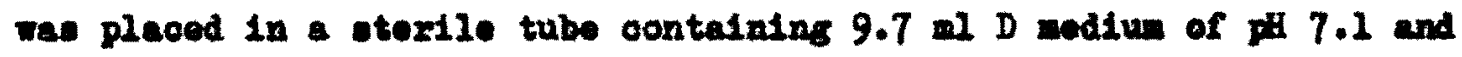
$0.1 \mathrm{ml}$ of an antiblotio. The drug used wore otroptomyoln and benayl peniodilins (the potaceium and sodiun salto of pandodilin 6). Final conoontrations of pentellitin ranged from .003 $\mu \mathrm{g} / \mathrm{ml}$ to $10 \mathrm{mg} / \mathrm{ml}$. Streptenvoin dosaces varied frce $.0003 \mu \mathrm{d} / \mathrm{ml}$ to $20 \mathrm{md} / \mathrm{al}$. The solutione 
TABTE II

$c_{E-10}$ moIth

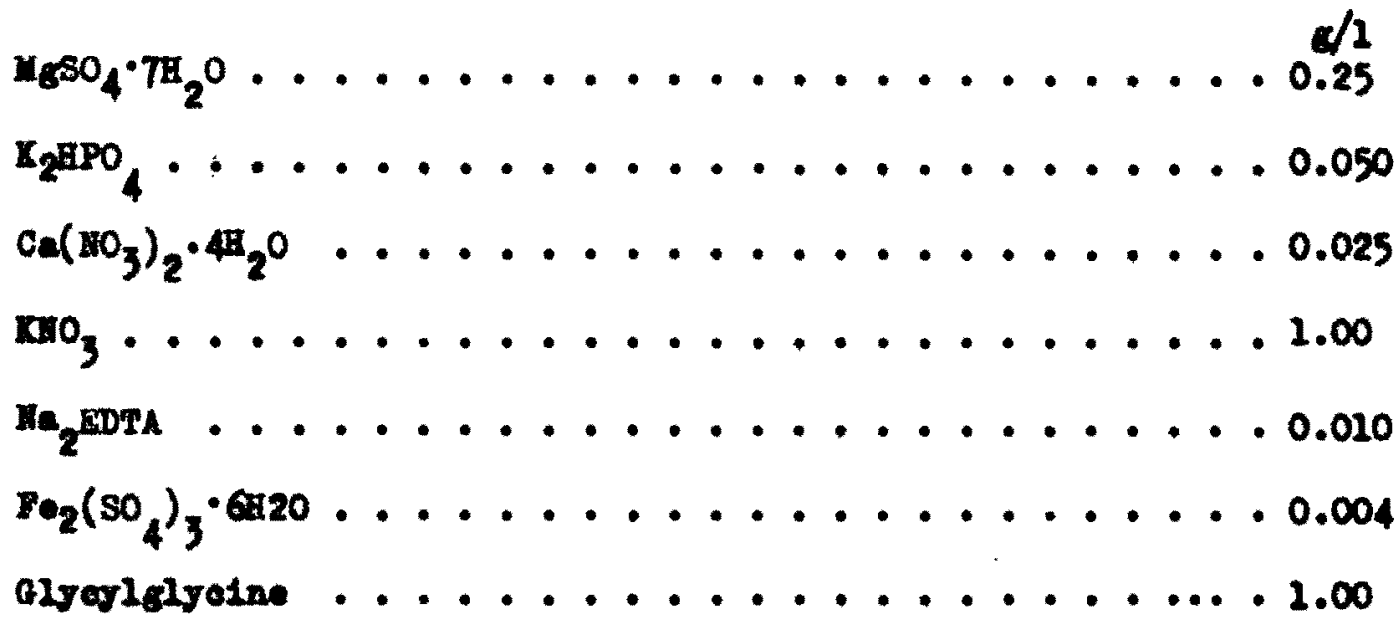

1.0 al of $1-5$ mlaronlomente Stook Solution.

\section{A-5 Mlaroelempts Stoak Solution}

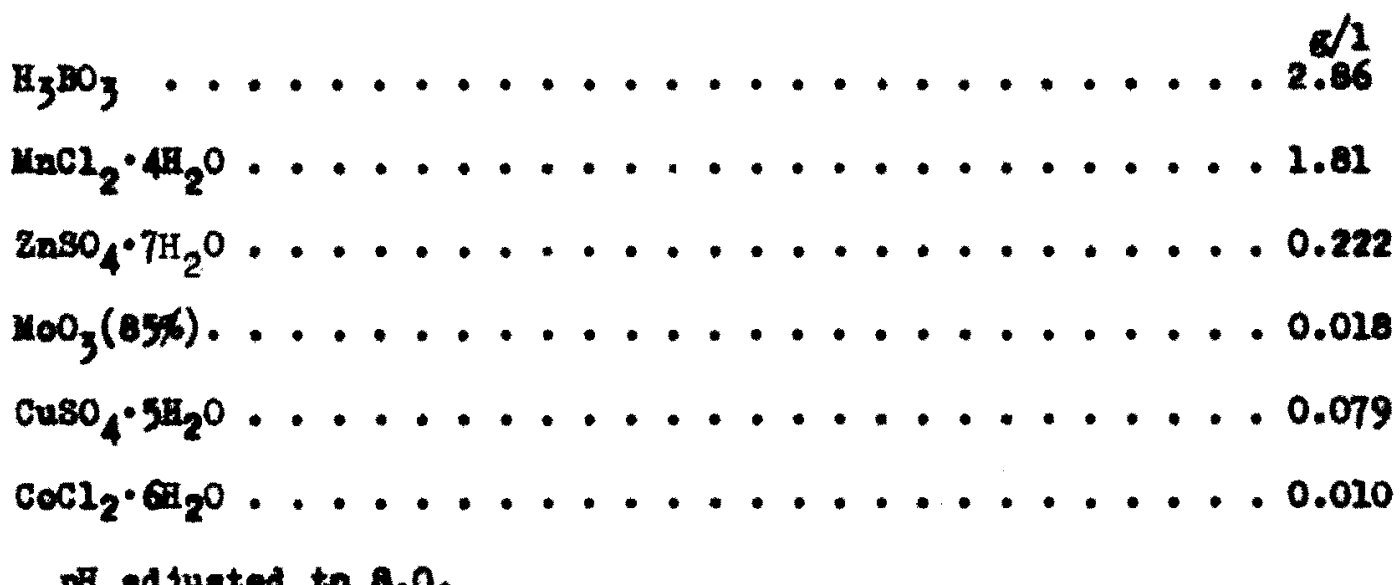

Pif adjueted to 8.0 . 
TABLE III

MEDIUI D

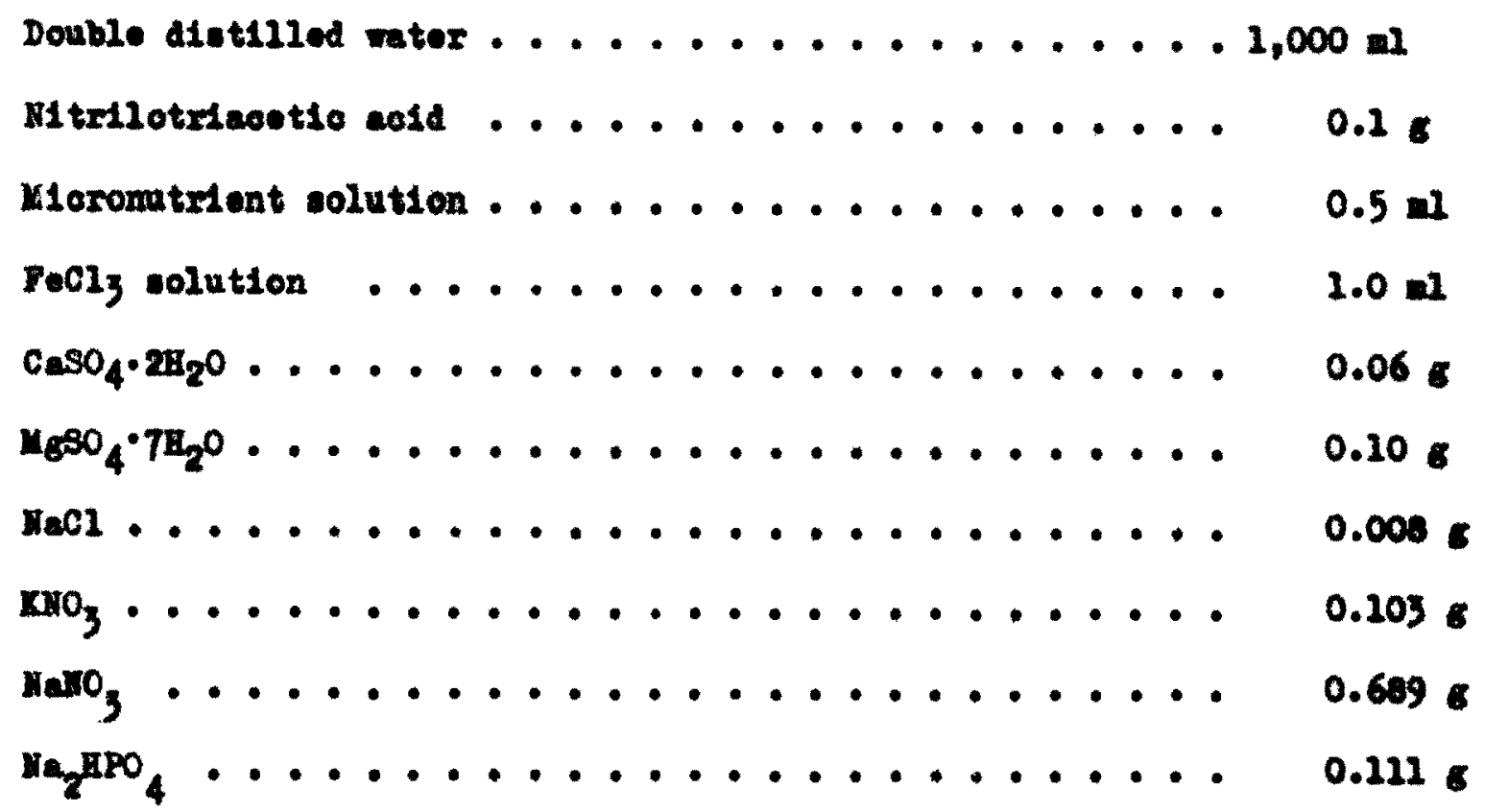

MICROMUTRIATT SOLOTIOH

DLet12ed water . . . . . . . . . . . . . . . . . 1,000 nl

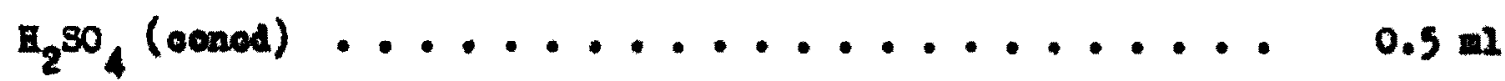

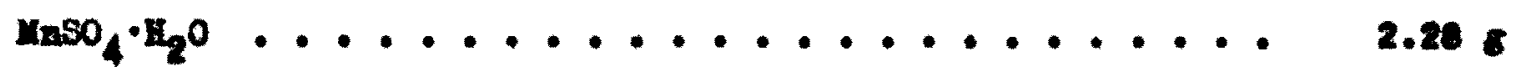

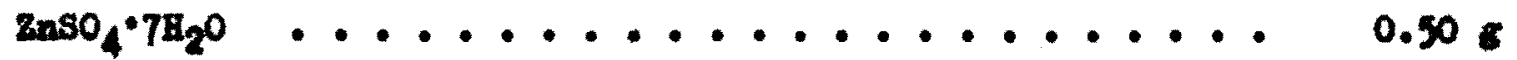

$\mathrm{B}_{3} \mathrm{BO}_{3} \ldots \ldots \ldots . \ldots . \ldots . \ldots . . \ldots . . . \ldots$

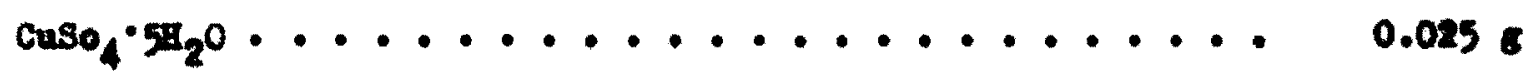

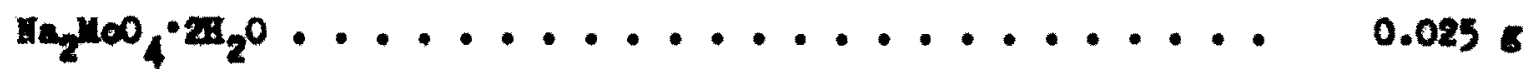

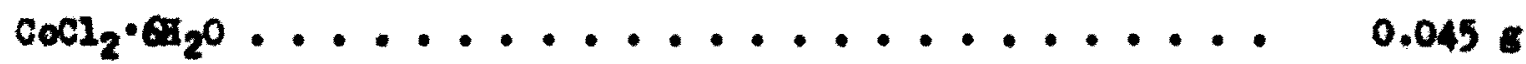

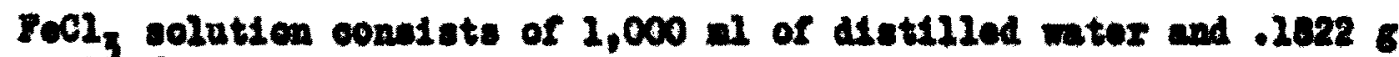
$7001_{3}^{3} \cdot a_{2} \mathrm{O}$.

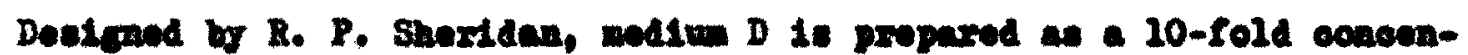
trated stook and stored at $4 \mathrm{C}$ unatoolaved. After dilution alth doublo

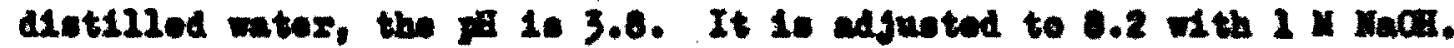
Tho final pil is 7.1 aftor the entoclaved nedim hes ocoled and elearod oonpletely. 


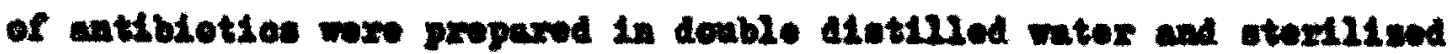

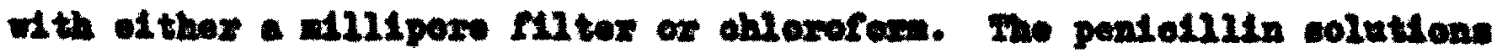

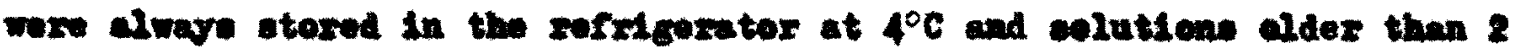
weks woro dimourded.

Growth wa reoosded by roading the optical dosolty on a Iott-

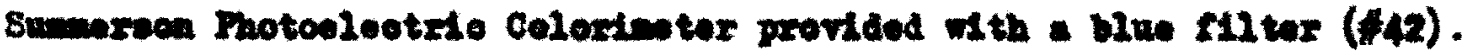

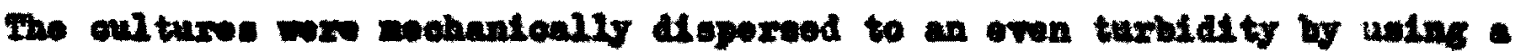

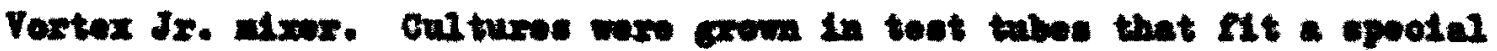
adapter in the colorimotex. Who tubes wore dosed with cotton-gause

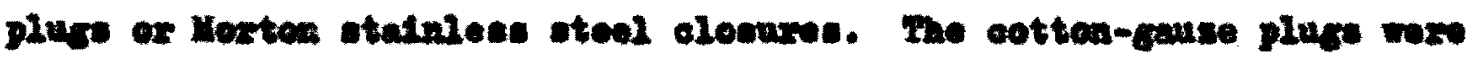

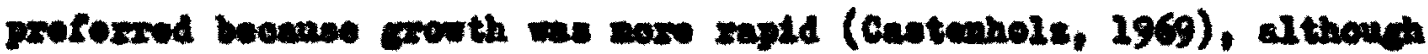

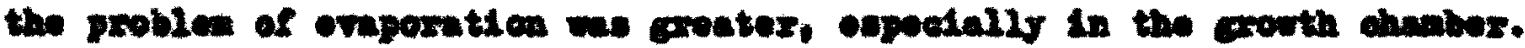

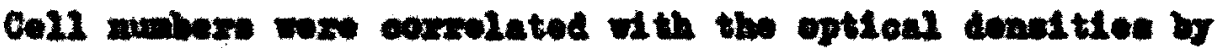

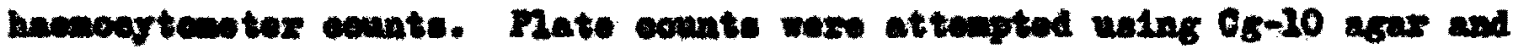

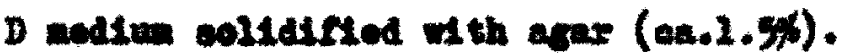

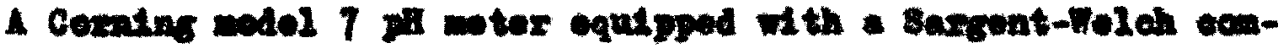

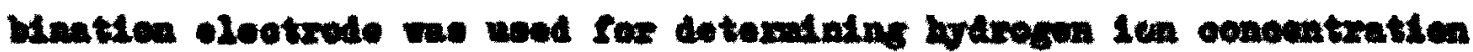

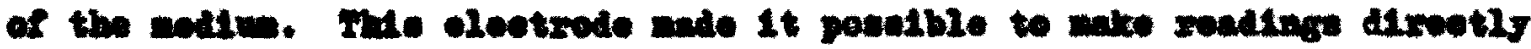

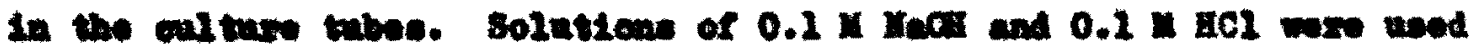

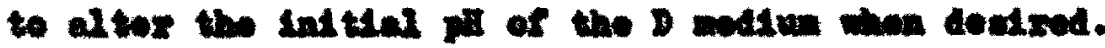

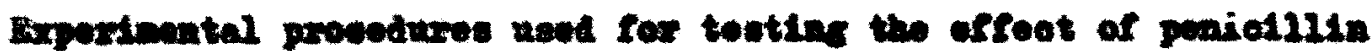

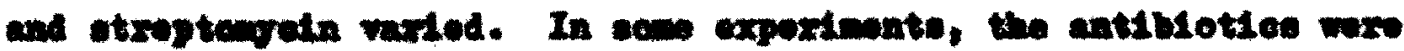
added at vardene poluts in the growth ourve. In othore, celle from

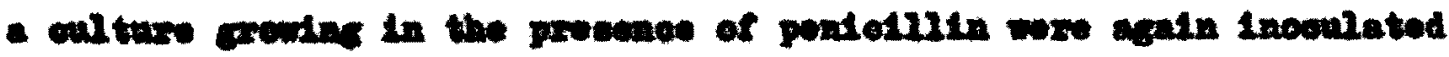

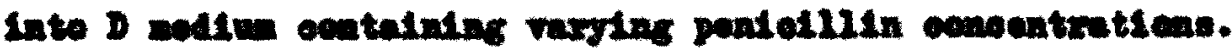


An extract wa taken frow an aotively growing oul ture oontaining ponielilin and was testod to doternine if pontollifinase was prosont. This was done by comparing the effoet of the extract with the sotion of peniodilinese (Beoto-Ponase, Difoo), obtainod frem Bsolllus op.

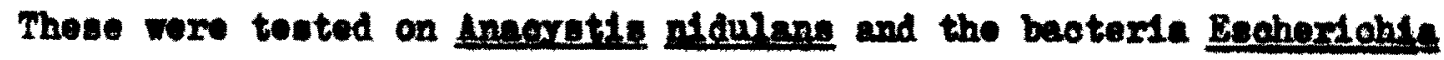
goll and Sarotng lutea. Those organians were flxod and otalnod by tho gratain.

Colls wore meanured uning a callbrated ocular mloromater on a Zeise light mtoroseope, nodel Wh. The filn used for piotures on the 11. int mloroseope was Kodak Panstonlo X, FX 120.

For electron sleroseopy, oell" wex eodimented by centrifugation (10 atn, $1500 \mathrm{mg}$ ) and elxed wth glutaraldehyde for tro hours, Finsed Wth $0.2 \times \mathrm{PO}_{4}$ buffor, and flxed 1 th 16 osminn tetroxide overnight. The noxt dey the camples were dehydrated in a graded sertes of acotonopropylow axde, and enbedded in Epon 812. Thin secttons wero out on a Porter-Blwa UT-2 mlexotowe wth glase kndres and plaked up on ourbonooated formvar apporte. Thase waxe double etained with uranyl sootate and lead oftreto, and photogrephed in a zeles eleotron merosoope, Moded

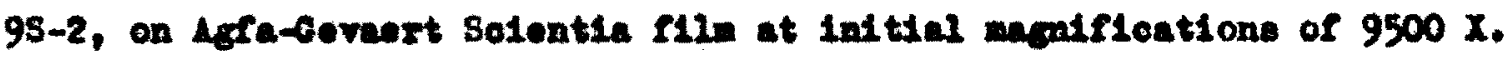
The graphe were senorated on a Control Data Corporation 6400 ocoputer by a prograx writton in the Morriul Ianguage and plotted on a Calcoup 670 plotter.

The orrantian

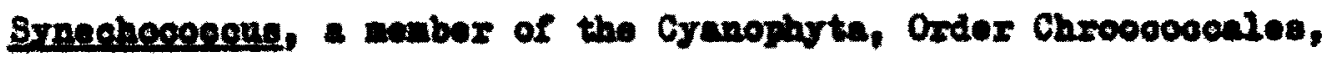
was firet noted by Hikeli in 1849 (Sinth, 1950). The alls of this 
gomas are usually colitary al though they way be in exoups of 2 to 4 al1gned pole to pole (See F1gure 6). The cella are ellipaotdal or cylindrical and are wthout an erddent gelatinous shosth. Beproduotion 1a by trangrerse cell divialon, nomally followed by eeparation of daughter cells. If separation doen not occur, 2-4 oelled oolontes w21 reoult. Individual rode moasure 2.2 to $2.2 \mu$ wide and 5 to $7.5 \mu$ lons. Anmoretis is also assigned to the Order Chroocosoales. The oolls are ell1pnoidal or aylindrical with broady rounded poles. A oheath 1. orldent around oach ooll although portions of shasths of oolle nay be confluent wthin a oolony wioh way number bundrods. Tho Individual oell. are 1.2 to $2.2 \mu$ wate and 1 to 3 times longer than broad. Onder oertatn oulture oonditions the colls tond to elongate and oells up to

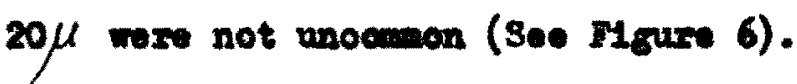




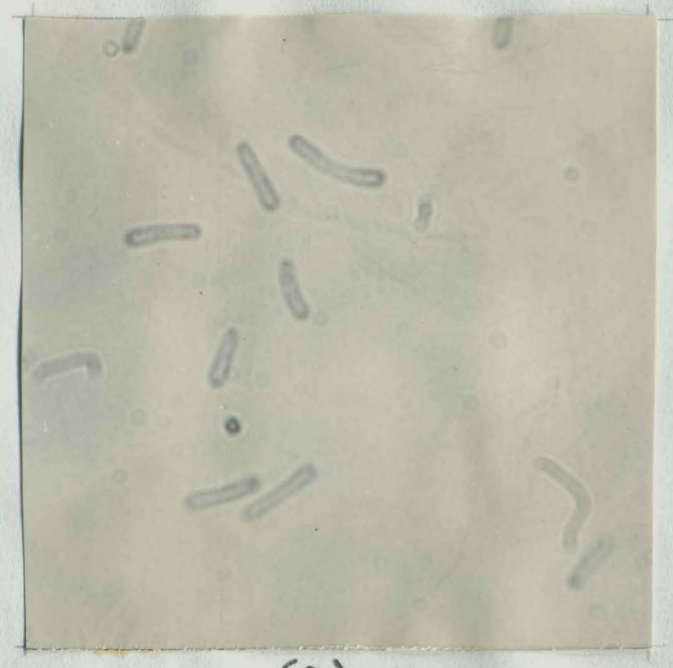

(a)

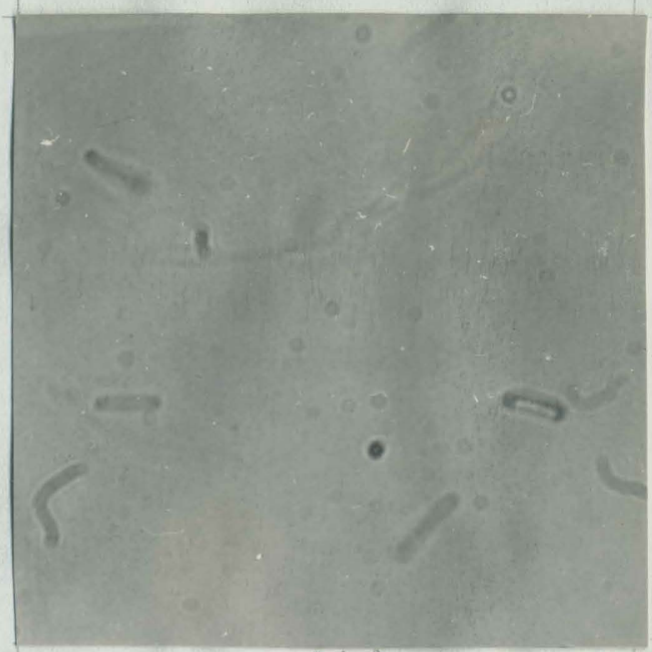

(b)

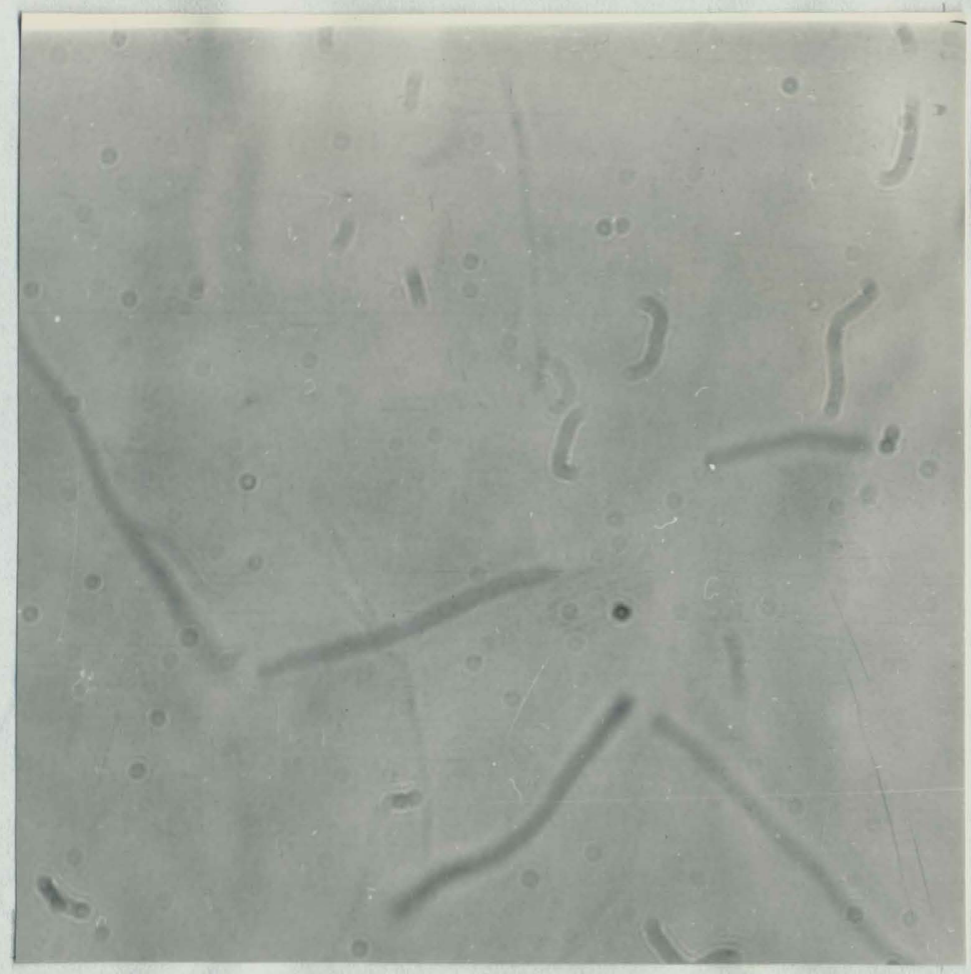

(c)

Digure 6. Hierophotogrephs of Symeehococcus lividue and Anecystis nidulans. a) S. 1ividus. $X 1350$ b) S. lividus after 4 hour treatment with $4.5 \mathrm{~g} / \mathrm{mI}$ Pen-K. X 2350 No moxphological differences can be noted between a and b. c) A. nidulans, X 2400 Elongated cells are not due to penicillin treatment, but occurred under normal laboratory conditions. 
RBSULTS

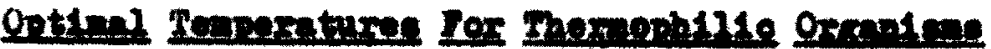

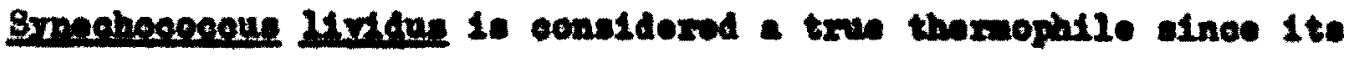

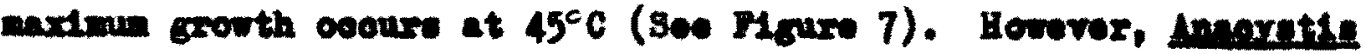

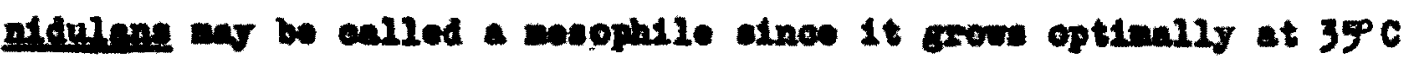
(Se0 Pigure 8). Those tenperatures axe too high to ellow murvival of

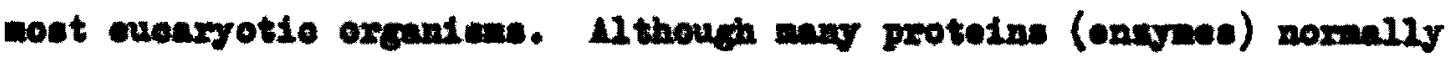
are not eotive at thene tonporatures, it apposse that the oells earry on photosynthesie and other setabollo cotivities at these ocmparatively high temperatranes. Brook (2967) found the mardmal mate of $24 \mathrm{C}$ photoInoorporation in matural population of Sxpenhoepoge takon fron several difforont tenperature regdeoe was very olose to the teaparature from

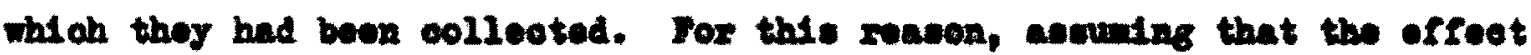

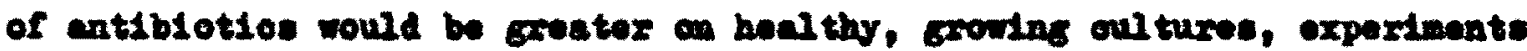
wexe earried out at the teaporature giving optinal growth for each organten.

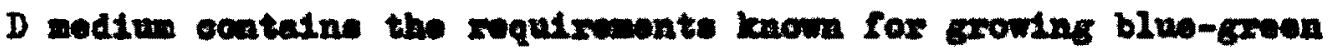
algae (Cantanhols, 1966, Oexloff, 2969). However, in D modiun diluted

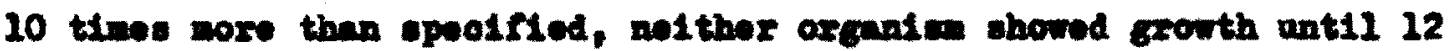
daye after Inooulation. This grenth ooourrod only at tholr optinal tomper-

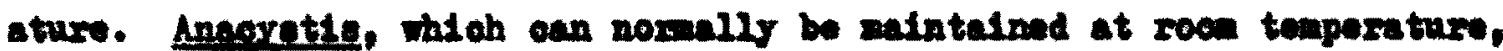

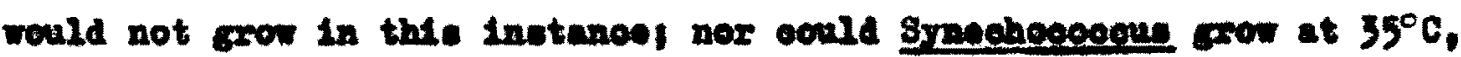
a tomperature that before had provided rapid crowth. Whon uutrionte worve alnisal, the other conditions hed to be optinal. 


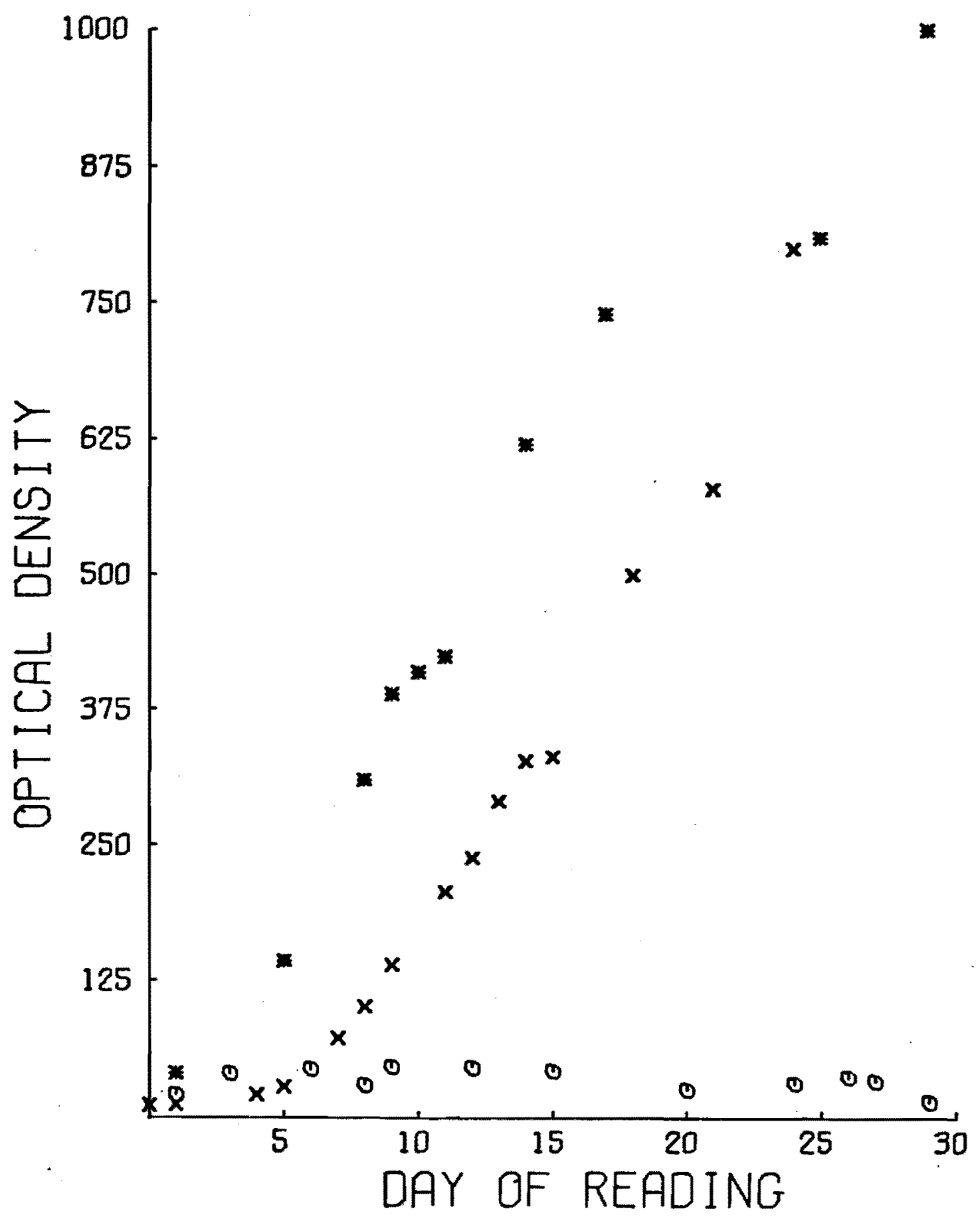

FIGURE 7. EYNECHOCOCCUG LIVIDUS AT VARYING TEMPERATURES. $*=45$ DECREEG $x=35$ DEGREES O $=25$ DEGREEG CROHTH VERSUS TIME. 


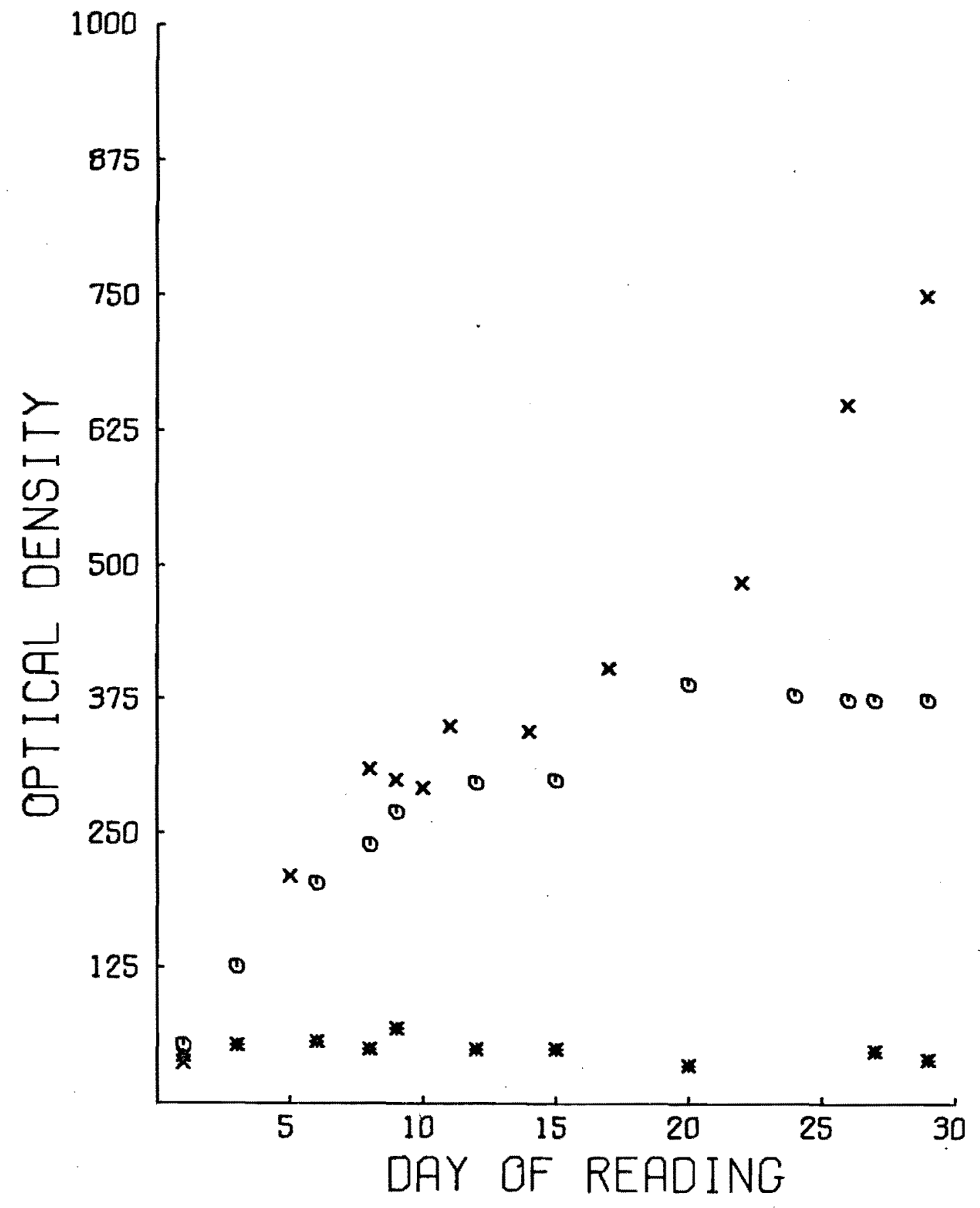

FIGURE B. ANACYSTIS NIOULANS AT VFRYING TEMPERATURES. $=45$ DEGREES $x=35$ DECREES $O=25$ DEGREES
GROWTH VERSUS TIME, 
Coll Counte

Plate ocunte wore attempted in an effort to oorrolate these wh th

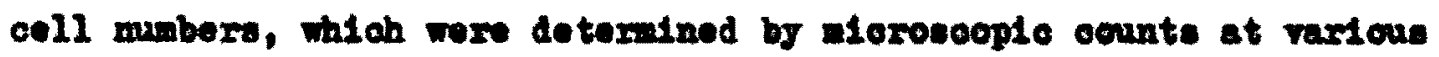
optlow denoltice. Howerex, alnoe not thex organta grow on $1.5 \%$ agax of

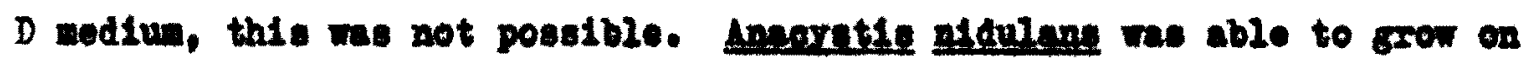
Cg-10 plates, but the results could not be quantitative becanes alngle oolondes were not obtainable upon dilution. This has been a problea before wth Anarertie (Van Bealen, 1967, 11102, 1969). Indeed, in an attompt to illuatrate eexrial exahange in bluo-grwon algee, Kunar (1962) could not aseort categorioully that mocoblnation ocourred within indifidual oelle because he was unable to grow elonos of Anseratin on solld sodie from single 0011s.

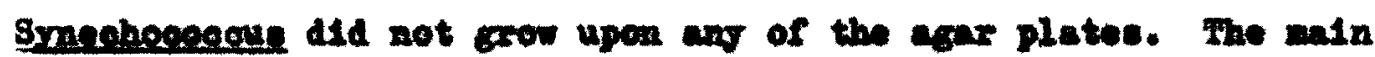
roasen for this fallure way have been thet the Potrl disber could not be put in a whex beth and thoxefore wor malntalnod only at $35^{\circ} \mathrm{C}$. This

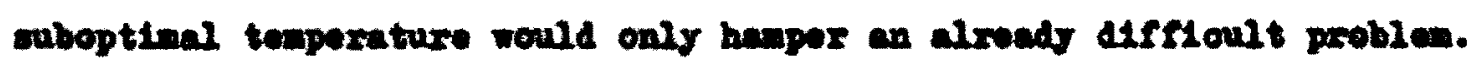

\section{Efreat of in on orenth}

The fll of the defined $D$ modium was usually found to be 7.2 aftor

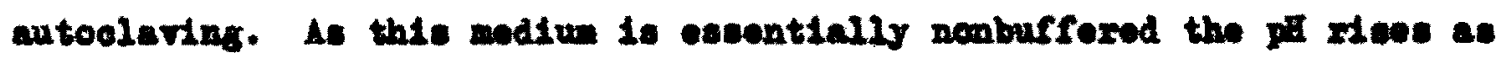
celle motabollsel 00 it was found that oollo oould grow in this modiun if

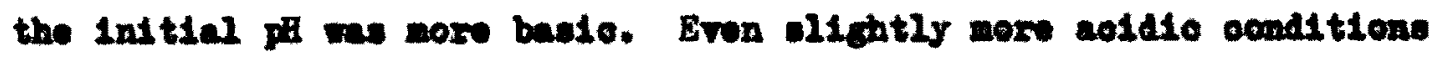
allowed growth to oocur.

Hydrogen $10 n$ oonoentration uovally dropped ellotily aftor the 106

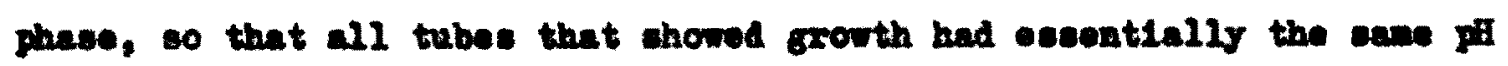
at the end of the growth ourve, regaxdiese of the etarting peint (80e 
Tables IV and V). All growling culturas of Syneghoogogue lividue attained a pif of $7.8-6.4$ at the end of the growth cyole. The final pile of cultures of Aneovatis nidulang in stationary phese (tubes 3-11) range from $7.7-8.4$. Tube 2 had 20 pD at f1ve days because the oulture had not yot begun to grow. Similarly, 1t's final pll is high because growth 1s contimuling. No growth was zeoorded in tubes 2,9 , and 10--10west and highest initial phis.

The Gxin statn

The gran etaln 1s uned to dfferentiate procaryotic organteme, apperently due to the difforont permeability of thalr cell walle. Difforont permeabilities imply different ocopounds or anounts of them prosent in the coll wall. The crow ataln was run on both tost organdsas,

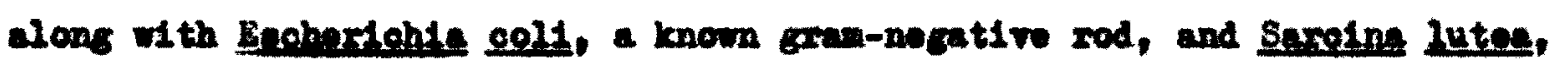
a cran-positive cosous. The reoults for the beoterle were we expeoted,

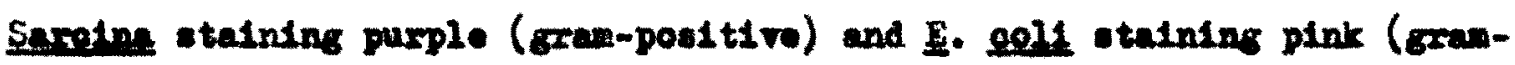

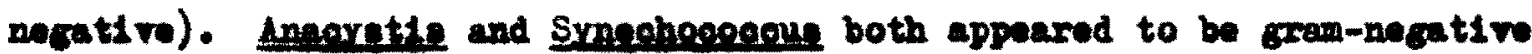
In this tost. Frow the it was inforsed thet ponselilin agth not hove

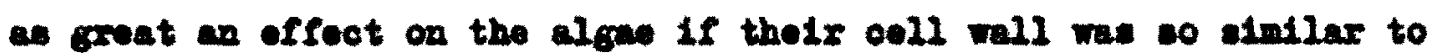
crom-negative bacteris. In addine peniolliln to E. soll, a chelating

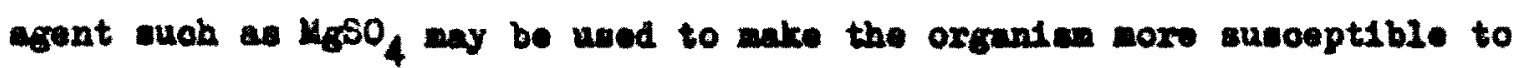
the antiblotio. Wo ahelating agonte ware uned with the blue-green algee when it wes dotorninod that ponsolilin was inhibiting their growth. 
83

THLE IV

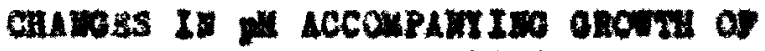

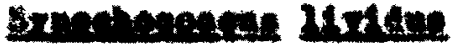

\begin{tabular}{|c|c|c|c|c|c|}
\hline ron: & InrTIt & 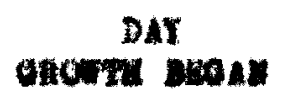 & 5 Dexro & 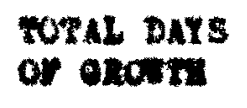 & rand $\boldsymbol{r}^{\prime}$ \\
\hline 2 & 5.1 & We anth & 5.1 & 25 & 5.4 \\
\hline 2 & 6.0 & 6 & 9.8 & 30 & 0.2 \\
\hline 3 & 6.5 & $5-6$ & 9.0 & 30 & 7.0 \\
\hline 4 & 6.0 & 4 & - & 25 & 0.2 \\
\hline 5 & 7.0 & $3-4$ & - & 25 & 0.4 \\
\hline 6 & 0.0 & 4 & 10.3 & 30 & 0.2 \\
\hline 7 & 9.0 & 4 & 10.4 & 30 & 0.2 \\
\hline 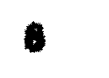 & 10.0 & $3-4$ & 10.4 & 30 & 0.5 \\
\hline 9 & $\mathbf{1 1 . 0}$ & $3-4$ & 20.6 & 30 & \\
\hline
\end{tabular}


TABLE $V$

CRAMESS IH FH ACCOUPARYINO GRONHH OF

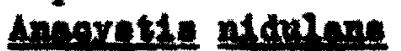

\begin{tabular}{|c|c|c|c|c|c|}
\hline TUBE & IBITIAL $\mathrm{pH}^{\mathrm{H}}$ & $\begin{array}{c}\text { DAY } \\
\text { GROWTH BEOAY }\end{array}$ & 5 DAYS & $\begin{array}{l}\text { TORAL DAYS } \\
\text { OF OROWTE }\end{array}$ & $\operatorname{minh}_{\mathrm{PH}}$ \\
\hline 1 & 5.2 & No growth & 5.2 & 25 & 5.4 \\
\hline 2 & 6.0 & 18 & 7.2 & 30 & 9.1 \\
\hline 3 & 6.5 & 5 & 9.9 & 25 & 7.7 \\
\hline 4 & $7 \cdot 4$ & 3 & - & 25 & 7.8 \\
\hline 5 & 6.0 & 3 & 9.5 & 30 & 8.0 \\
\hline 6 & 9.0 & $2-3$ & 20.2 & 30 & 8.0 \\
\hline 7 & 10.0 & 2 & 10.4 & 30 & 8.0 \\
\hline 8 & 11.0 & $1-2$ & 21.0 & 30 & 8.4 \\
\hline 9 & 12.0 & No growth & 12.0 & 25 & 9.9 \\
\hline 10 & 12.5 & Io srowth & 12.5 & 25 & 12.1 \\
\hline
\end{tabular}


1ffect of Pentcillin On Anacystis nidulang

The sodium and potassium salts of pentcillin were added to $D$ wedium at the same time as the inoculum. The lowst concentration that inhibited growth in most cases was $3.0 \mu g / m l$. Growth appeared to be normal at concentrations of $0.03 \mu_{\mathrm{K}} / \mathrm{ml}$ and below. An Initial lag phase of 6-17 days was observed with $0.3 \mu \mathrm{E} / \mathrm{ml}$ present, whereas controls had a $18 \mathrm{~g}$ of about 2 days (See Figures 9,10, and 11).

The sodium salt of pentcilin o (Pen-Ne) appeared to give a shorter lag, but lag phase was so variable that this cannot be definttely stated. Although differences were not as great, it should be noted thet some variation occurs in normal growth ourves.

\section{Erobsble Explanations For Survival In Pontoll11n}

Soveral experiments were conducted to test poselble explanations for the survivel of Anacystie atdulang in the presenoe of pentcilin. Collo treated with penioillin may here become resistant to 1 t by a mutation allowing them to survive. These mutated cells could grow and outnumber the sensitive ones present. If this were the case, these cells ghould more readily survive another contact with the antibiotic. However, an inoculum from such a culture gave the same length lag phsee as stock oellef nor were the treated cells able to survive higher concentrations of the drug. Therefore, it does not seem likely that the origin of drug resistant mutant strains was a faotor here.

Secondly, survival in the presence of pentoillin oould be due to the breakdown of the antiblotic by the enzyme pentollitinase. If this enzyme were beling produced by the algae, growth should occur with little 


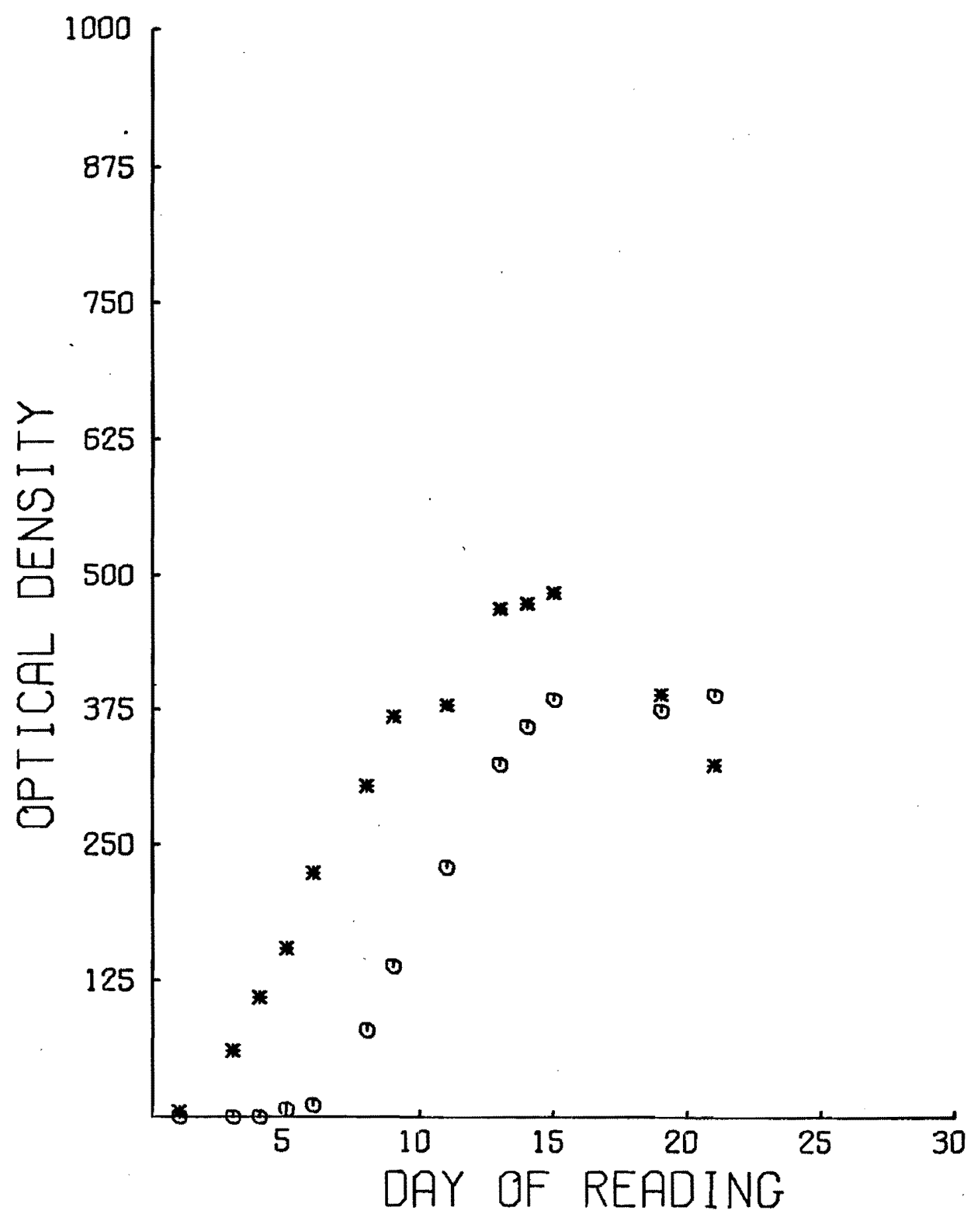

FIGURE 9. FNRCYSTIS NIOULANS WITH PEN-NA PRESENT. CROHTH VERSUS TIME. $m=$ CONTROL. O $O=$ HITH 0.3 MICROGRAMML PEN-NA. 


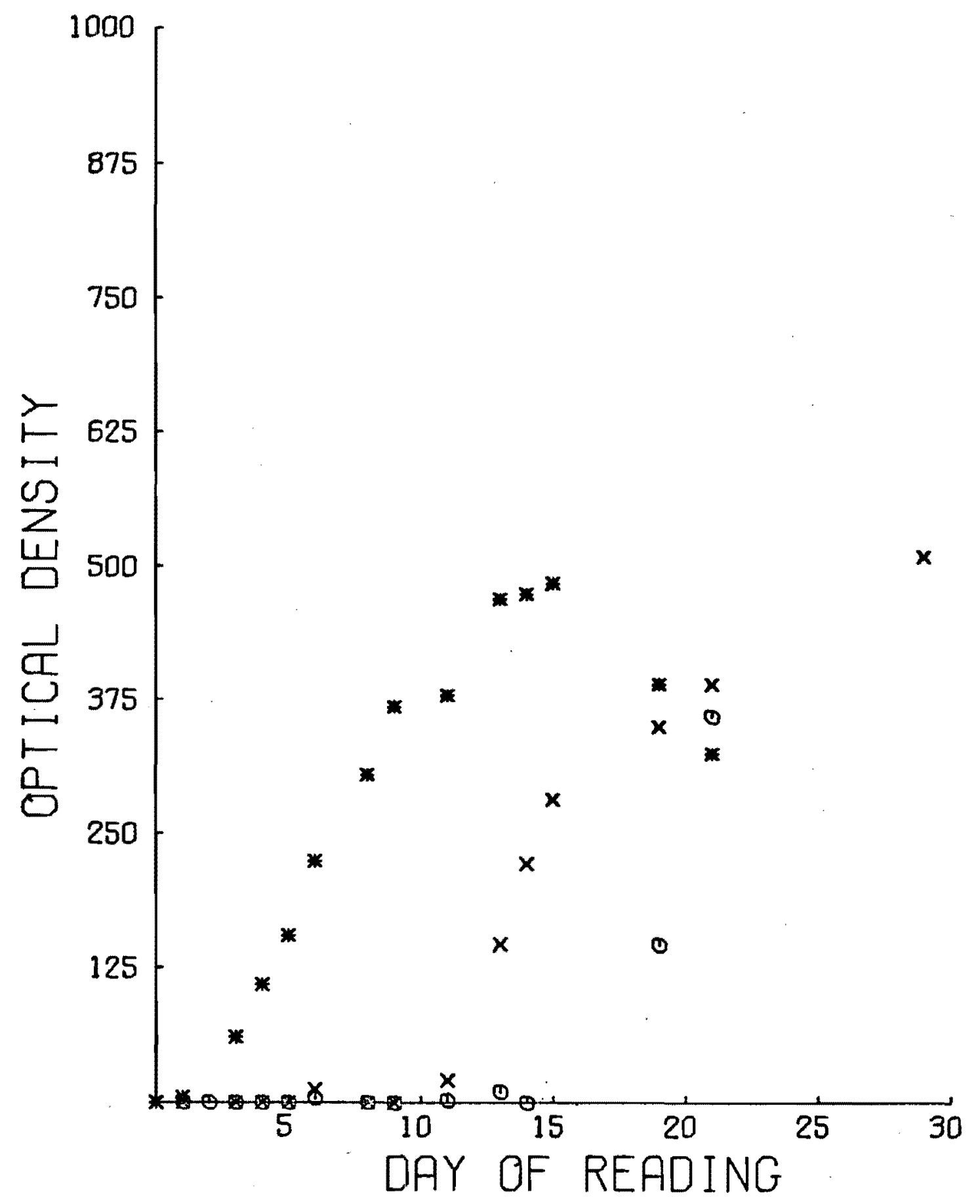

FICURE 10. EFFECT OF PEN-K ON ANACYSTIS NIDULANS.

GROHTH VERSUG TIME, *=CONTROL. $X$ SODUPLICATE TUBES CONTRINING 0.3 MICROCRAMUML PEN-K. 


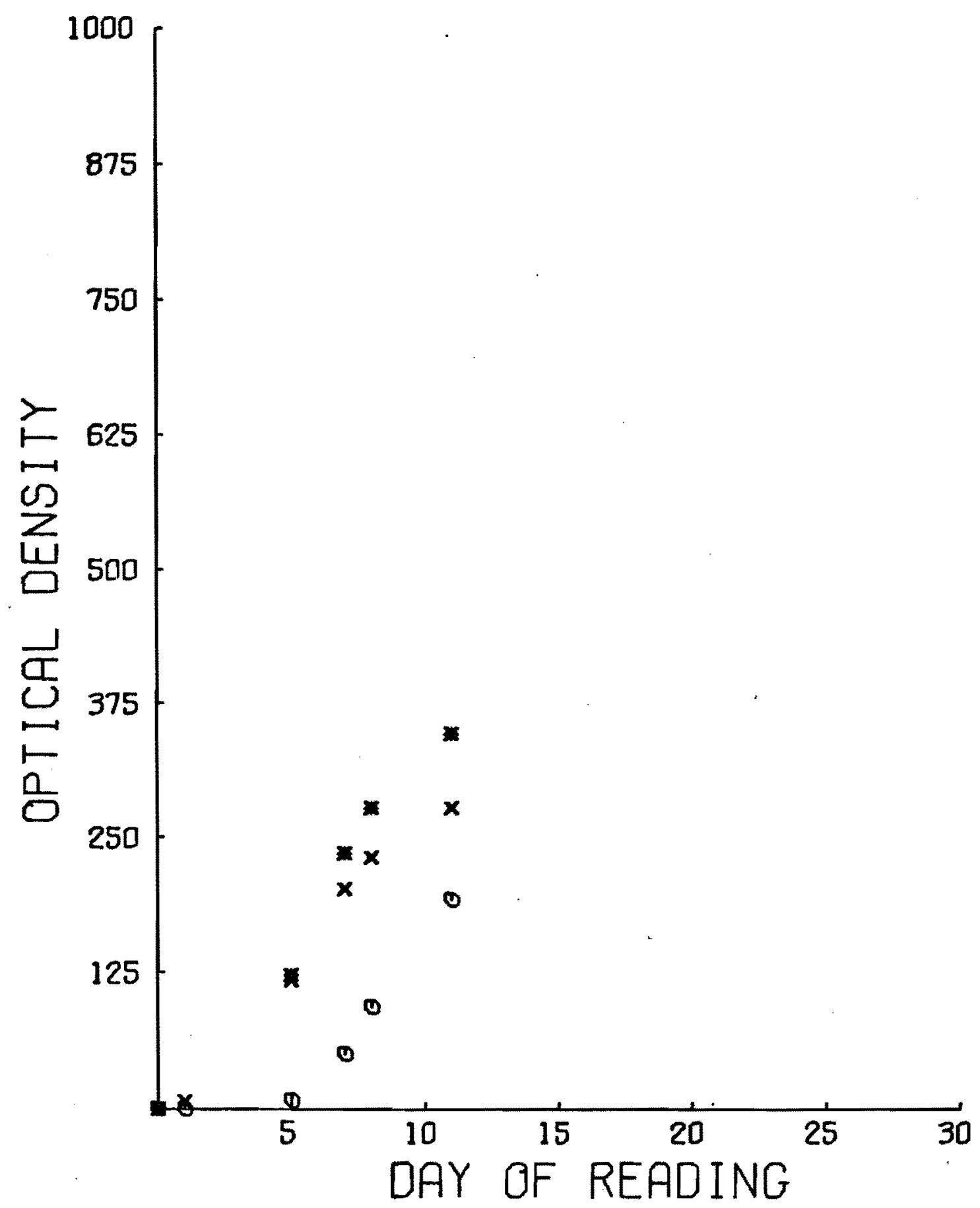

FIQURE 11. EFFECT OF PEH MA ON ANACYGTI6 NIQLAFIS NITH INOCULUM TFAEN FROM A 5 DAY DLO CULTURE. ECCNTRQ. $X=.03$ MICROCRAM/RL PEN-NA.

$O=0.3$ MICRDGRRIIML PENTNA. 


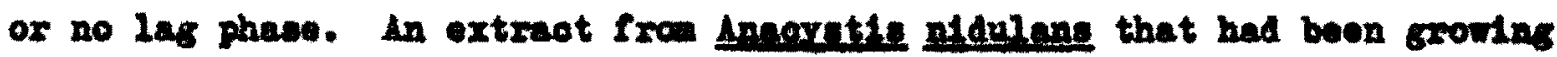

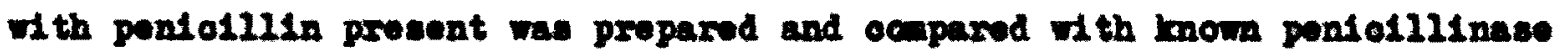

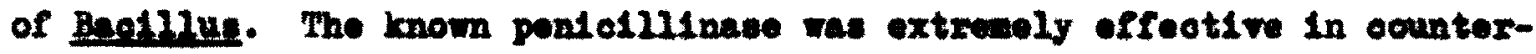
aoting the aotion of the ponicilin when tested on oul turee of Ansoretie. In all but one experimontal tube, the aleal extreat did not appoar to contain the onsyme (Soe Mgare 22). Cells in the tost tube with 0.3 $\mu d^{\prime 2 l}$ of pentolilin plus the extraot began growing at about 0 days after Inoculation. Otherwise, the oultures ather showed a greated intitial

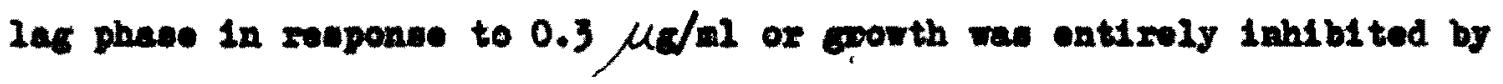
the peniol211n. Sinee oubequont expertente of this type did not reveal any further excoption, it soces improbable that the alga axe produating a pentoll11nase.

In addition, the pentell21nese from Beatllue and the algal oxtraot

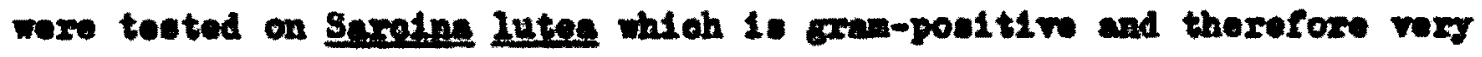
conative to ponioli21n. Addition of the antiblotio aused the celle to

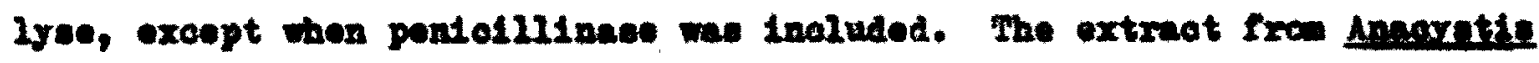
did not oounteract the effoet of the antibiotio.

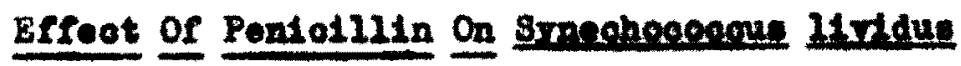

The Inttiel 2 ag phase noted in the roupones of Anogyatie to pen-

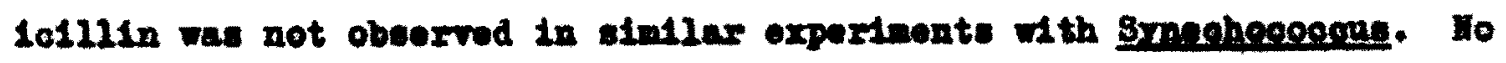
growth was obeerved in oul tures to whoh $0.03 \mu \mathrm{d} / \mathrm{ml}$ were added at the the of inooulation. However, celle troted with $0.003 \mu \mathrm{d} / \mathrm{ml}$ of Pon-Ha showed no differenoe in exowth patterns from the oontrols. 


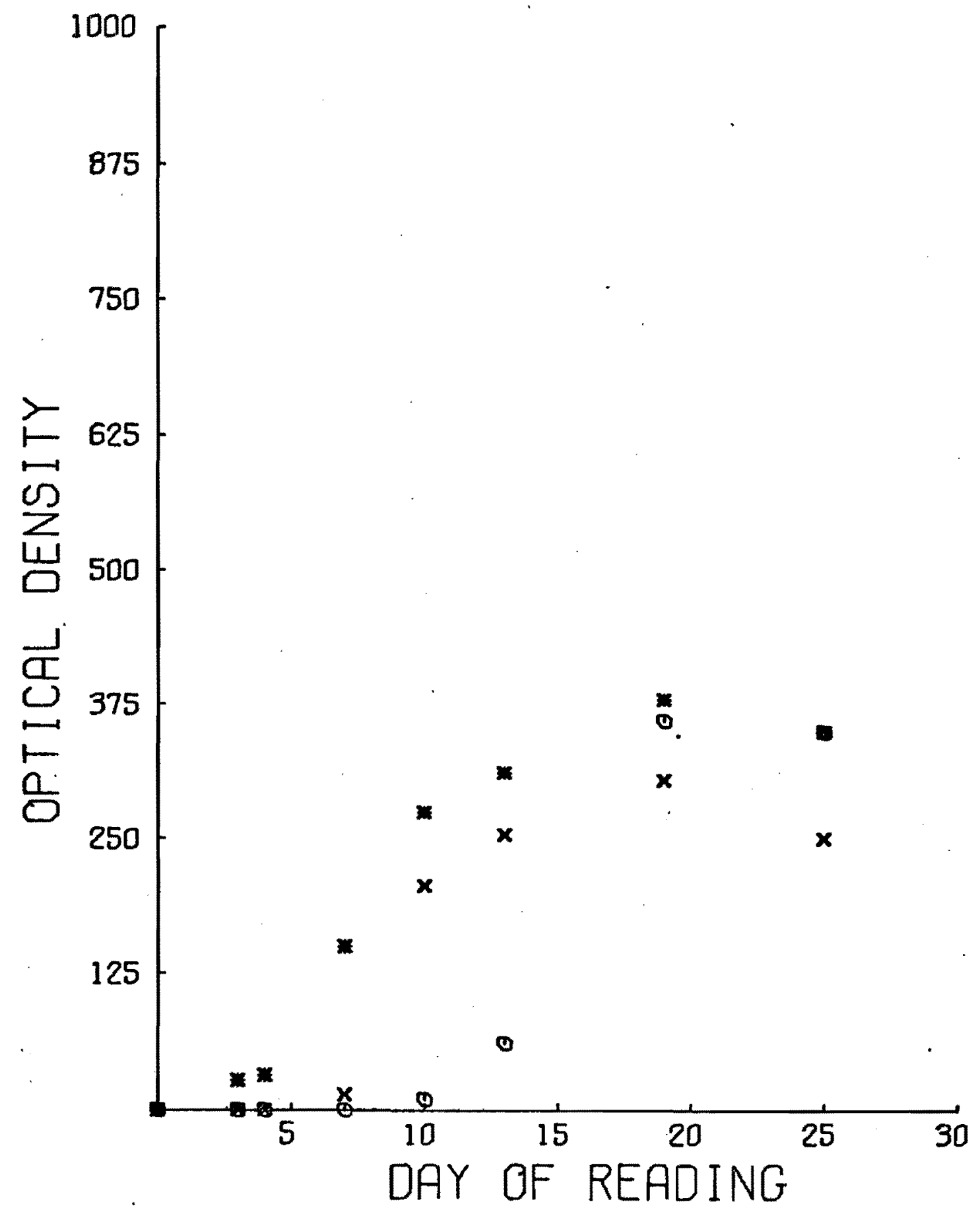

FIGURE 12. TEST FOR EFFECT OF PENICILLINASE ON FNACTSTIS NIDURANG

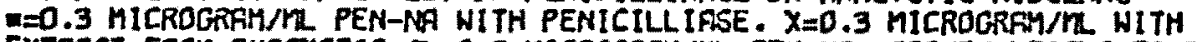
EXTRACT FROM ANRCTSTIS. O=0.3 MICRDGRAMIKL PEN-NA. GROHTH VERQU6 TINE. 
Bffeot of Streptomrein on Anacyetis And Smeohocoeque

When concentrations of atreptamoin of $0.03 \mu \mathrm{d} / \mathrm{m}$ or above were added at the time of Inoculation, growth was Inbiblted in both organders. Ho Initial lag phase wes observed in these experdmonts and results ohowed

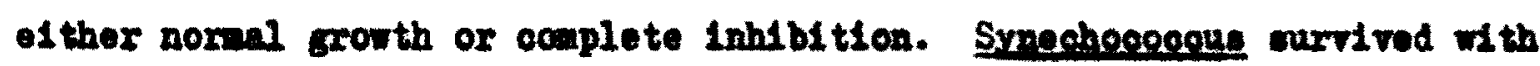
$0.003 \mu \mathrm{g} / \mathrm{ml}$, woreas Annoyetis Grow with $0.006 \mu \mathrm{d} / \mathrm{ml}$ added. When $1.5 \mathrm{mg} / \mathrm{ml}$ stroptomoln was added to a Smophoepaque in 208 phase, Growth leveled off for approxdnately one woek and thon began to deorease. The deoreace in Amagratle howeror, was moxe repld and quito obvious the firet day after otreptoureln was added (See F1orarea 13 and 14 ). 


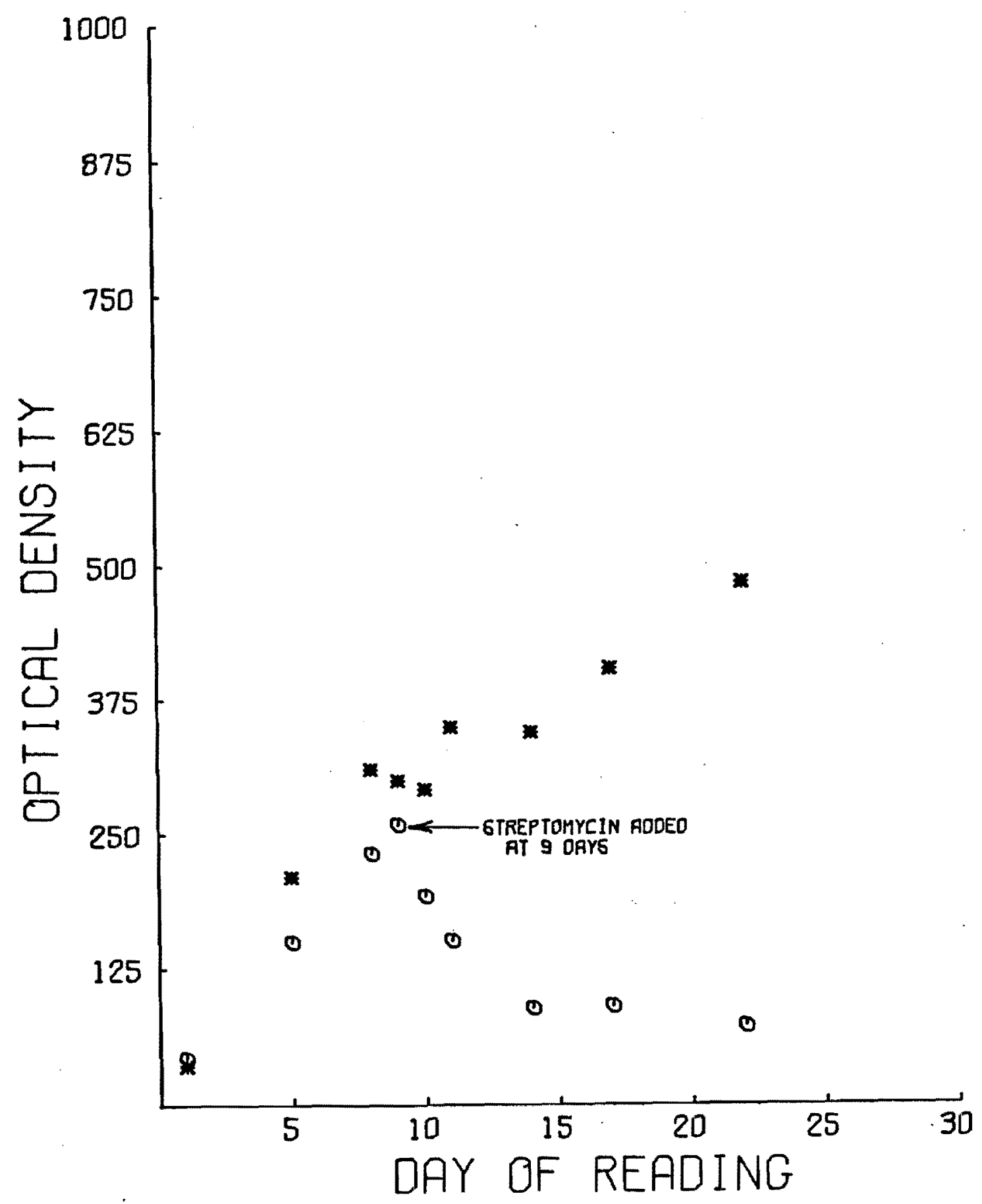

FIGURE 13. EFFECT OF STREPTOMYCIN ON FNACYSTI6 NIOULANG. GROWTH VERGUS TIME. 


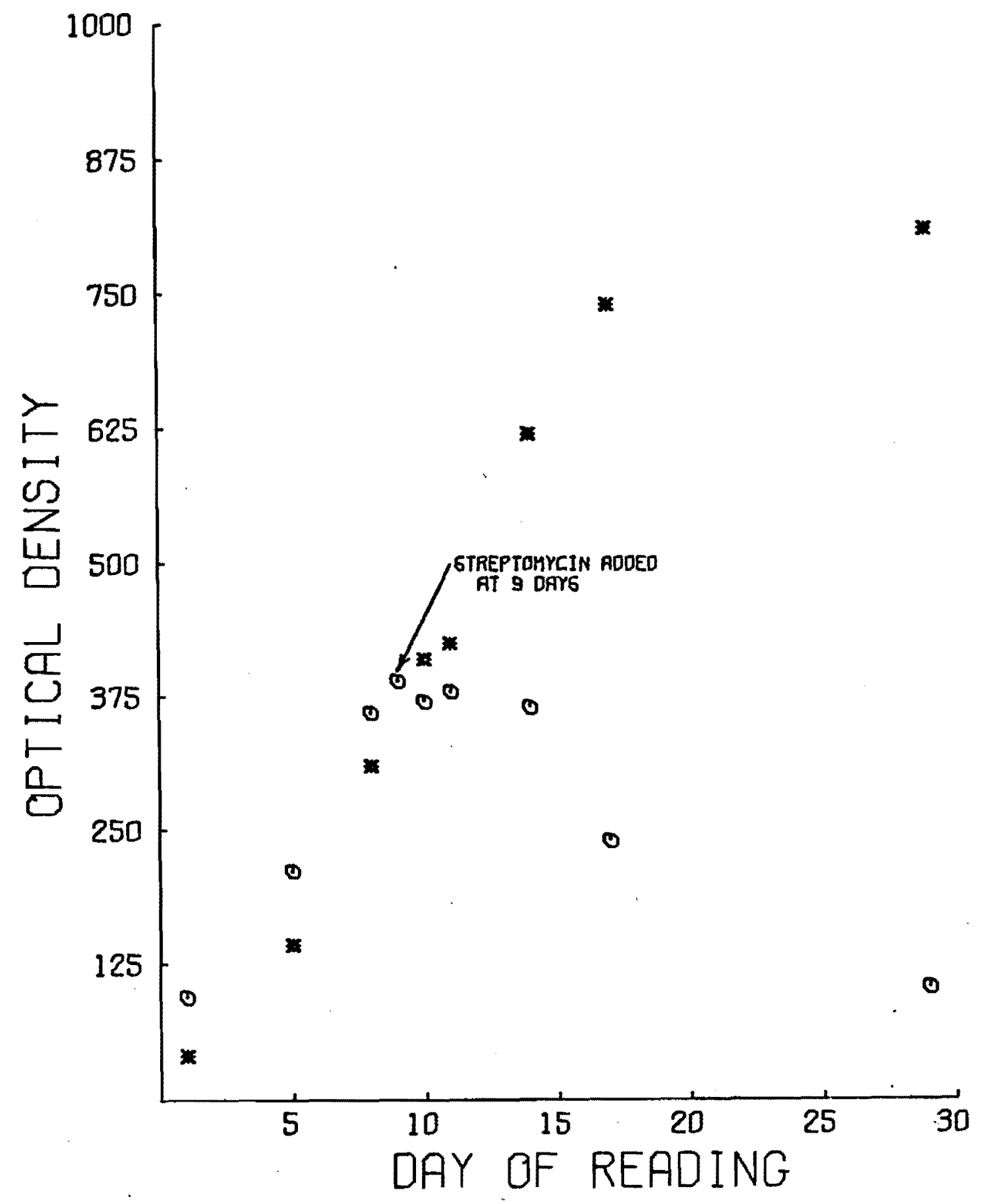

FIGURE 14. EFFECT OF STREPTOMYCIN ON SYMECHOCOCCUS LIVIDUG.

OROHTH VEREUG TIME. W=CONTROL. O=WITH GTREPTOHYCIN. 


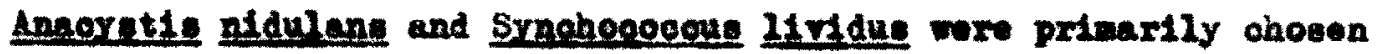
experimental organd san beoause it wae deened highly desirable to use pure cultures and these were the speoles that were fortultouly avallable in axento condition. 1s woxk progreseed it boowe roadily apparent that these algae were adrantageoue for other reasond as well. They grot reaconably well in the media ueed and reaohed comparatively large cell numbers per unit volwa. In eddition, einoe growth was reoordod by onploying optical donatity toohniques, it was nocesanry to have homogonocus solutions. Of the aany bluo-green algae tested, thene two themophille opoelee ahowed homognneous growth or, in seme cases, formed pellet whioh oould be reedily and evenly diepereed throughout the nodiun. Also, beouse inoreasing temperatures of lakes and streame are current world problems, it soems that more information on thermophiles wil be of value.

A wde range of Intial pie allowed growth of both test organimas. Al though $D$ modium is an escentially unbuffered solution, it was observed that final we we in the narror range of $7.7-8.4$. The faot that highor initial pHe tended to gtve ellghtly higher finel phe was not ooneidered to be signifioant.

The literature seens to indloate an agreement anong workere that the cell walls of blue-green algae are olmilex to gram-negative becteria (Frank, Lefort, and Martin, 1962). Drowe and Meyer (1964) say the Iucopoptide layer in bluo-green algae 1o admilar to that found in granpositive beoterie. Recently, K. J. Bacin (Personsl ocmmenioation) notes the 
contradiotion of Aneoretie ntdulens boling soneltive to quit to low concentration of ponioillin, and yot belng olased as gram-nogative. The

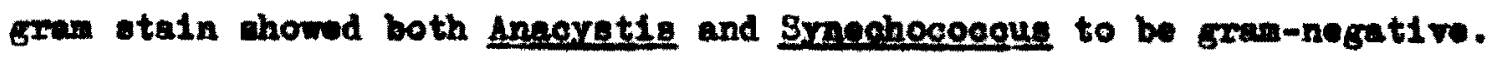
W1th only this evidence, however, it would perhaps be tenuous to state they are wore similar to gran-negative becteria, even though it is more Generally agreed that this is the case.

Al though pentellilin does not usually affect gran-negati ve organd ses as easily as gram-positive, there was the appearanes of an Inttial las phase in tests wth hreoystis. The reason for the observed Ing in Anaoyetio with $0.3 \mu \mathrm{g} / \mathrm{wl}$ of penlolilin present, cannot be definitely stated. Bxperisents gave no eridenoe that matant otraine may have arisen, aince celle growing with pontolliln present did not react differently than untreated cells when again exposed to peniclliln.

There was virtwally no experimental evidenoe to euggest that pen101111nase was beling produod by Angergtis and therofore the posalbillty that thls could be the factor causing the intilal lag phase is ruled out. Sinos there was only one instance in whloh the presonoc of the algal extraot appeared to Inhibit the action of penfollilin it any be thet thie we des to experimental excor. Thls ability to counteraot the sctivity of the drug in this exceptional ouse could poselbly be due to an earlier autational erent. Howover, this oulture was got tostod agnin before disourding and no sonoluatons cen be rade.

It 10 known that ponfolizin zap1diy detorforetes whon kopt at tomperatures above $4^{\circ} \mathrm{C}$. It is probable, then, that sene oells ourvive until the high teoperature destroy the pendolilin! thon aftor as apperont "las", cont1me to crow. 
It 10 also poseible thet the nature of the inoouln is ardioal in deternining whothor or not there is an intilel lag phase, since differont ace oultures were ueed as souroes of the ortginal inoeulum. Howerer, experimente abowed that cells taken from f1wo daya, fifteon daye, and frea oldex oultures in the stationary phese of crowth, gare the previounly noted 1 es phase.

In an experiaent Just reoontly ooploted, inooule from a nlue day old oulture were unable to currive in $0.03 \mu \mathrm{d} / \mathrm{al}$. Those oelle, from the log phase of growth, were probably able to begln growth imediately and thair Inability to anthosise now ooll wil ald not allon ourviral. Celle from the stationary or las phase an requirs an intilal lag bofore thoy oan bogln growth in now modia agein. It would secen thet the 5-dey old oultures whould have given the same remelts, alnoe they appear to be In the 208 phase aleo. In view of the frot that these regul to sees contradlotory, it wey be that the phyolologloal oondition of the oelle raxy Inoenaletently as they 60 from one phase to the noxt.

Ron-lla appeared to oause a shortor las phese (about 6 deva) thas did Pon-X (9-17 daye). Thlo diffownoe an be due to ellghtly diffozont binding properties, whoh in twrn are the recult of difforent lone prosent. Pen-lla say not be as olose an abalogue to the opeetrle cell wall cemponent as Pen-X, which vould mean fower cells would be affected. Ox, it way bo

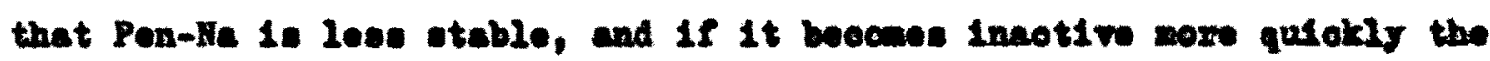
murviving colls oould grow more rapldly in its presonos.

Howerex, sean variablitty ocoursed in the controls. Varlability

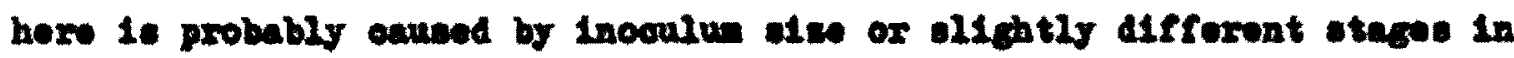

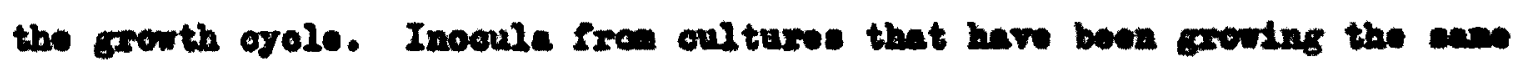


number of day ay not be in the cano physiologloal condition. Plppetting exrore, variable onviromontal condition (1noubetion tenporatures and light intenalty), and the posalbility of oontamination of the cultures all oen Introduce experimontal varlabllity.

It ceoas a bit umumal that Smeghoopeque 10 so easily attacked by pontallin, and yot is maletent to 1 ywompe action. The oell well of

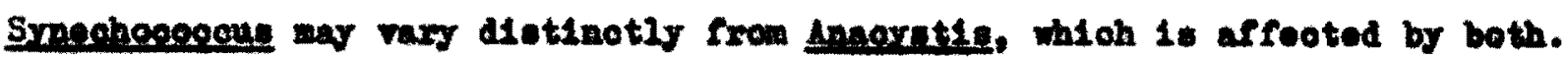

Stroptongoin had an inhibltory offeot on both organlame at a certaln conontration. Thls is underetandable sinoe enough runotional protolns mant be mede for the oell to ourrive.

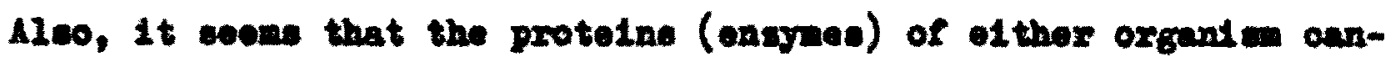
not runotion at $55^{\circ} \mathrm{C}$, stnoe no srowth cocurred at the tonperature. They have adapted to boowe thoxnophilee but they are not able to withstand Inoxeatingly highor tenperatures.

\section{Surrontion For Fusther Berenseh}

It has beon apperent throughout the oouree of thil Inventigation thet oertain refinowents ilcht have been dealrable. The linted apeoe

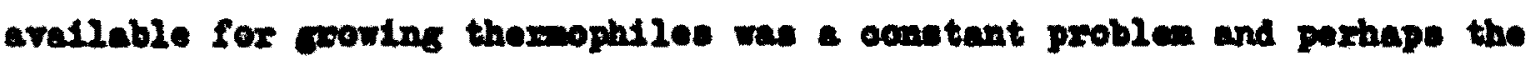
use of hot water bathe in plwoe of additional crowth chmbere was not as efflolont. Also, no attenpt was made to get cultures in myohronous Erowth and this alght prove to be anerul athod in deternining the factor(a) controlling such obeervable phonowne as the latilal lag phase response to oertaln 1evels of pontodilin.

It was hoped that it would be posalble to obtain eleotron merographe whloh rould prove valuable in dotermining the serpholegtow obanges 
assoolated Ith fallure of cell wall synthosis. Although moh tive and offort we opont in the attempt, the mlerographe obtainod have not boon of suffiolent quality to inolude in this research. 
Sunary

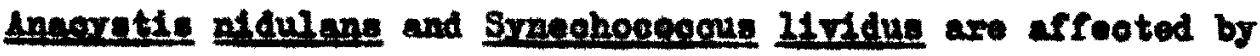

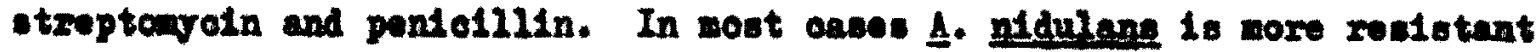

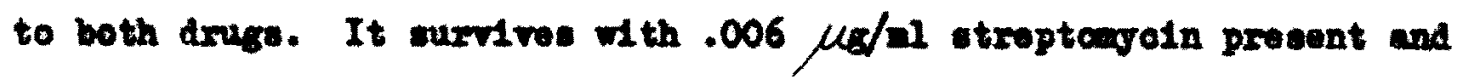
$0.3 \mu \mathrm{c} / \mathrm{ml}$ of pentollitn thexwas S. Hritue was only able to grow in $0.003 \mu d / 2$ of both antiblotios.

The growth pattern of Smephopoepese was affected in the wame wannor by both druge. There was el ther norwal growth or ocmpleto inhibition. 11 though etroptanyoln had almilar effeot on Anearet1e, it resotod differently to poniolilin.

W1 th the lowest oonoentration of pondollin allowing growth $(0.3$ $\mu \mathrm{d} / \mathrm{m})$, Ansorctie was observed to have an Initial 198 phase that was longer than the aentrole. Thls intilal phase in the growth ourve was not observed in Smaphoepecus. Onoe the las poriod was over however, these oul tures uevaliy attained the same maximal crowth as whineted oultures. A ratety of poestble masone for the lac portod are dicoused. 
COMCLOSIOR

The work hore has, oorroborated the recults of the previous woxkere who have shown that the oell wall of bluo-creen algec is sinder to

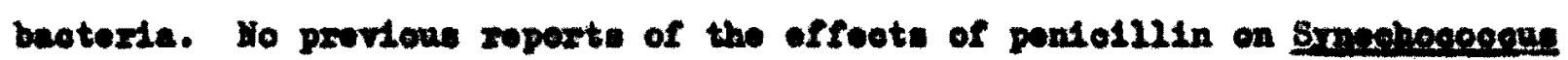
have beon seon, wo this woxk has produced additioned ofidenoe to cupport tho cupposition that bluo-grena elgas seopond to ant1blot1os in wheh the eano why as thols proseryotio relatives tho becteria. 


\section{LITERATORE CITED}

Mlen, Maxy Mennos. 1968. Growth of Untcellular Blue-0reen Algae on Plates. I. Phycol. 4t 1-4.

Betterton, J. C. and C. Van Baalon. 1968. Phosphorue Definolonoy and

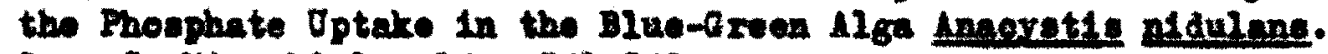
Can. J. Mlorob101. 141 341-348.

Basta. H. J. Pereonal comantoation.

Brock, T. D. 1967. U1cro-organioms adapted to Htgh Temperatures. Nature 214: 802-885.

Centenholx, Blohard W. 1967. Environmentel Requirements of Thormophilio Blue-Groon Algae, p. 35-79. In A. F. Bartaoh (od.), Enviromontel Requlrement of Blue-Groon Algeo, Fodoral Water Pollution Control Adminletration, Corvallss, Oxa. - 1969. Thermophille Blue-Green Algae and the Thermal Enviroment. Bact. Rev. 33: 476-504.

Chatterf1a, B. A. and Robert P. W11L1ans. 1965. Formation of Spheroplaete Iro Baplliue anthreele. I. Bacteriol. 69. 1228-1133.

Collino, J. F. and K. H. R1ohnond. 1963. A Struotural sindlard ty

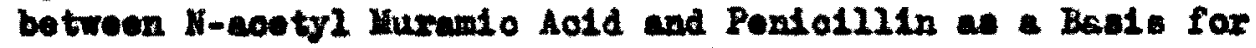
intiblotio lotion. Heture 2958142.

Cont1, S. F. and H. E. Qettrex. 1962, Blootron Mlarosoopt of Collular DI vision in Eenertohie 9e24. J. Bacteriol. 83: 544-550.

Cox, E., J. R. Whit to and J. O. Rlaks. 1964. Streptowroin Lotion and Ribocones. Proo. Ilet1. Lead. So1. 51: 703-709.

Crenpl, H. L., S. E. Manderlile, and J. J. Kats, 1962. The Lotion of Lysozyme on Several Bleo-Green Algae. Bloche. Brophre. Beg. Come. 9. 569-573.

Dealkachary, J. V. 1959. Cyanophyta. Aoadento Preses, Now York.

Drowe, O. and H. Moger. 1964. Unteroughungen swo Oheni sobon Lurban der

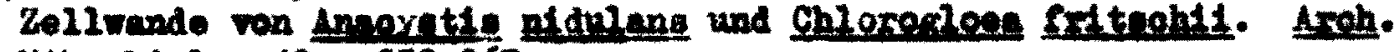
uirrobiol. 408 259-267. 
Fitz-James, Philip and Roneld Hancock. 1965. The Initial Struotural Leaton of Pontosilin Lotion In Bacllue mentertu. I. Cell Blol. 26. 657-663.

Flynn, E. H. and C. W. Godseskd. 1967. Pontolllins and Cephalosporins, p. 1-39. In Darld Oottliob and Pawl D. Shan (od.), Antib1otion I. Springer-Vorlas, Now York.

Yrank, H., Maroul20 Lefort, and H. H. Martin. 1962. Chemtoal Analysio of Hucopolyner Component in Cell Falle of the Blue-Green Alge Phormtatum unotnatum. Blochon. Blophre. Bes. Cosw. 7t 322-325.

- 1962. Elektronenopt1sohe und Chemteah Bntereuchunger an

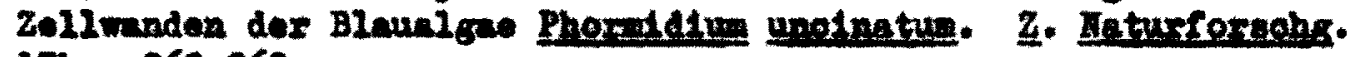
27b: 262-260.

Gexloff, O. C. and X. A. Fishboak. 1969. Quantitative Cat1on Requirements of Several Green and Blue-Groen 12ewe. Je Phreol. 5i 109113.

Gupta, R. S. and H. D. Xumar. 1970. Aotion of Mutagento Chenticale on

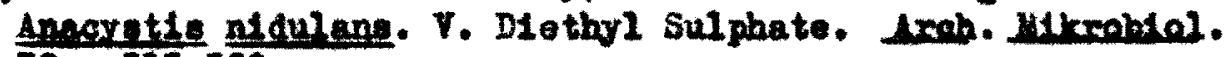
$70,313-329$.

- 1970. The Jffeot of Melolo Hydraside on Growth and Mutation or a Blue -0 roen Alga. Arch. Mikrobiel. 708 330-339.

Holm-Hanuon, Owand, Rebandra Prasod, and Ralph Lewin. 1965.

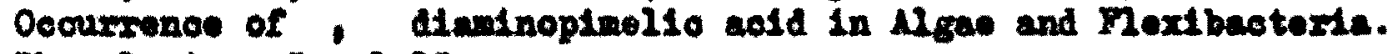
Phyoolerde. 5: 1-15.

Krats, W. A., and J. Hyers. 1955. Iutrition and Oronth of Several Bluo-oreen 11 gao. Amex. J. Bet. 421 282-287.

Iunar, H. D. 1962. Apparent Qenetio Roocmbienation in a Blue-Green Alga. Iatax 196: 1121-1122.

Lang, Horna J. 1968. The Fine Structure of Blue-Oreen Algae. Ang. Hex. Moxpb101. 22: 15-46.

LIndery, Jorry K., B. Dwain Vanee, Joe S. Keetex, and Vernon E. Soholea. 1971. Sphoroplest Formation and Assooleted Ultrastruetural Changes

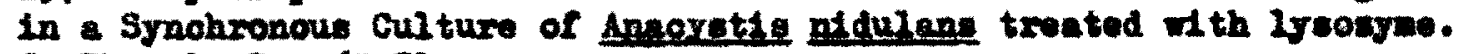
I. Plareal. 71 65-72.

Mahler, Eonry R. and Eugone B. Cordes. 1966. Blologioal Chomiatry. Harper and Row, Hew York.

Mandelotem, J. and X. Mopustlen, (ed.). 1968. Blochendetry of Baoterial Growth. John Filey and Sons Ino., New York. 
Murray, R. G. E., P. Steen, and B. E. Elson. 1965. The Localization

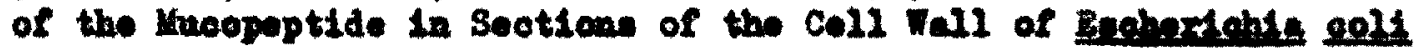
and other Gran-nogative Baoterla. Cen. J. viarobtol. 11. 547-560.

Novikoff, Alex B., and Brio Boltzman. 1970. Cella and Organelles. Bolt, Hinchart and Finoton, Ino., How Ioxk.

Park, James T. and Jack L. Strominger. 1957. Mode of Action of Pentoll11n. Solenee 125, 99-101.

P1kálek, Petr. 1967. Attempt to Find Recombination in sparretile mldulene. Hature 215:

Punnott, T., and Ethyl C. Derrenbecker. 1966. The Anino Aold Componttion of Algel Cell Walls. I. Gen. Miexe. 44: 105-114.

Riohnond, H. G. 1966. Struotural Analow and Chomios Reactivity in the Aotion of Antibecterial Compounds, p. 301-335. In Blochnaloel Studies of Antialorobial Drugs. The Sjndios of the Canbridge Univeralty Press, Londion.

Hogere, H. J. 2963. The Beoterlal Cell Wall. The Reault of Adeorption, Struoture, or Selootive Porweabllity? I. Gen. Morabiol. 32. 29-24.

Salton, H. R. J. 1957. The Properties of Lywowy and Ite Lation on Heroorganians. Betertol. ReY. 218 82-99.

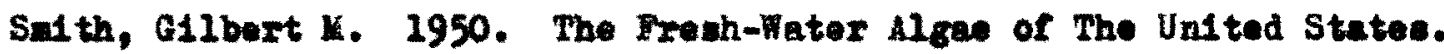
Hof raw-Hill Book Company, Hew York.

Srivastave, B. S. 1969. U1tra-710lot Induoed intations to Growth Feotor Requiremont and Pontatilin Realetenoe in a Blue-Green Alge. Srah. urrohiel. $66: 234-236$.

- 1970. Sornttivity and Resiatanoe of a Blue-Green Alga

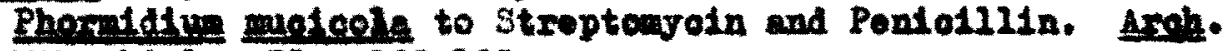
Groptol. 72, 182-185.

Starr, Riahard C. 1964. The Culture Colleotion of Algee at Irdians Univerefty. Alex. J. Bot. 51, 1013-1044.

Ssybalak1, and Sodium-p-andno-salloylete. I. Beat. 66: 460-469.

Ven Baslen, C. 1967. Turthor observations on Growth of single celle of Coovold Blwa-Oneen Algee. I. Pryeal. 31 154-157.

Weldel, W.. H. Frants, and H. H. Lartin. 1960. The Rtgdd Larer of the

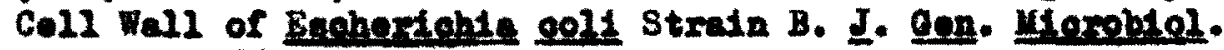
$22.158-166$. 
We1del, T. and J. Primonigh. 1957. Dle gavelnoame Wursel der Lyse

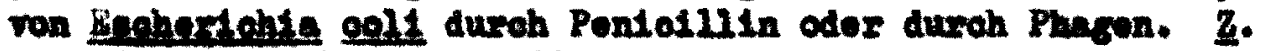
Ieturforeals. 12, 421-427.

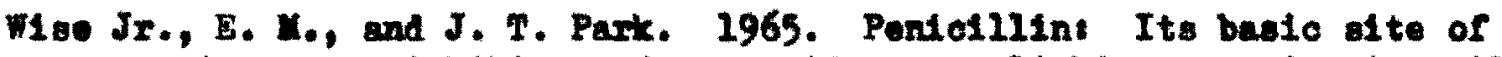
cotion as an Inhibltor of a peptide orons-1inding meaction in coll wall moopoptide oynthento. Exee. Hatl. Land. So1. 54875. 